\title{
Gelişmiş Batı Demokrasilerinde Sivil-Asker îlişkilerine Dair Farklı Çözümler
}

MUTLU YILDIRIM*

yildirimmutlu@hotmail.com

ORCID ID:0000-0002-0465-1949

Öz: Demokrasi, siyasal katılım, özgürlük, insan hakları, eşitlik gibi temel evrensel değerlere dayanan, bugünün çoğunluğunun yarının azınlı̆̆ına dönüşebileceği, azınlı̆̆ın haklarının çoğunluk hakları kadar tanındığı bir yönetim biçimidir. Bugün siyasi yelpazenin farklı kesitlerini temsil etmesine rağmen, demokratik olduğunu iddia etmeyen bir rejim bulmak oldukça güçtür. Ancak o kadar geniş bir alanı etkisi altına almasına rağmen demokrasi üzerinde yapılan tartışmalar nihayete ermemiş, ortak kabul gören bir demokrasi modeli benimsenmemiştir. Ülkelerin farklı sivil-asker ilişkileri tecrübeleri ile toplumsal yapıları birbirinden farklı demokratik sistemlerin ortaya çıkmasına neden olmuştur. Ancak en son kertede özellikle gelişmiş Batı ülkelerin evrensel demokratik ilkelerin kabul gördüğü bir sisteme evrilmesine, sivilasker ilişkilerinde katetmiş oldukları mesafe ve sahip oldukları siyasi kültür katkı sağlamıştır. Bu çalışma, gelişmiş Batı ülkelerin farklı sivil-asker ilişkileri tecrübelerine ışık tutarak ortak, pekişmiş bir demokrasi kültürüne sahip olduklarını ortaya koymayı amaçlamaktadır.

Anahtar kelimeler: Siyaset, Demokrasi, Batı ülkeleri, Sivil, Asker.

\section{Giriş}

Demokratik rejim dünya çapında özellikle II. Dünya Savaşı sonrasında yaygın bir kabul görmeye başlamıştır. 1989'da Sovyet Sosyalist Cumhuriyetler Birliği (SSCB) ve Doğu Bloku'nun çökmesiyle başlayan süreçte, tüm dikkatler Doğu Avrupa ülkelerine çevrilmiş, Huntington’n “demokratikleşmenin üçüncü dalgası” adını verdiği liberal demokrasinin küresel yükselişi, demokratikleşme çabalarına yeni bir boyut kazandırmıştır. Demokratik gelişme sürecini tamamlama anlamında ciddi mesafeler almış Batılı ülkeler ise geçmişinde ciddi bir sivil-asker ilişkileri bagajını taşıyarak bugünlere ulaşmıştır. Söz konusu bu ülke örneklerine geçmeden önce nihai hedef olarak belirlenmiş olan demokrasi konusuna eğilmek çalışmaya ışık tutacaktır.

Tüm siyasi topluluğun üyelerinin veya vatandaşların devlet politikasını şekillendirmede eşit hakka sahip olduğu bir yönetim biçimi olan demokrasi, Oxford Kla-

\footnotetext{
* Dr., Siyaset Bilimi ve Kamu Yönetimi.
} 
sik Sözlüğü’ne göre ilk olarak Atina’da bir tiranlar hanedanlığını iktidardan indiren ayaklanmaların ardından, İ.Ö. 5. yüzyıldan İ.Ö. 4. yüzyıla geçilirken ortaya çıkmıştır. Demokrasi genellikle devlet yönetim biçimi olarak değerlendirilmesine rağmen özellikle eski Yunan'daki filozoflar Aristo ve Eflatun tarafından eleştirilmiş, halk içinde "ayak takımının yönetimi” gibi aşağılayıcı kavramlarla nitelendirilmiştir. En başından itibaren partizan, çatışmalı, siyasi yönetim felsefelerini ve toplumsal sinıfları ayıran bir sözcük olarak kabul edilip, iyi bir siyasi yönetimin zorunlu koşulu olmakla birlikte, yeter koşulu olmaktan uzak olduğu belirtilmiştir. ${ }^{1}$ Fakat demokrasi diğer yönetim şekillerinin arasından sıyrılarak günümüzde en yaygın kullanılan devlet sistemi haline gelmiştir.

Asıl dönüm noktasını 1776 Amerikan Bağımsızlık Bildirgesi ve 1789 Fransız İhtilali ile yaşayan demokrasi, özellikle insan hakları, özgürlük ve eşitlik anlayışı konusunda oldukça önemli konuları dünya gündemine taşımıştır. Amerikan Bağımsızlık Bildirgesi’nde bütün insanların özgür doğup yaşadığı, devletin görevinin bu özgürlükleri korumak ve herkesin eşit olarak yararlanmasını temin etmek olduğu hükmü yer alırken, bu özgürlüklere dokunan devletin kendi varlık nedenini yitireceği, böyle bir devlete karşı ayaklanmanın da hem bir hak hem de ödev olduğu vurgulanmıştır.

Bugün artık siyasi yelpazenin farklı kesitlerini temsil etmesine rağmen demokratik olduğunu iddia etmeyen bir rejim bulmak oldukça güçtür. Çok sayıda farklı tanımı yapılan demokrasinin, Diamond'ın belirttiğine göre, Collier ve Levitsky tarafından 550 farklı biçimi ortaya koymuştur. ${ }^{2}$ Bu kadar farklı demokrasi biçiminin olmasının nedeni siyasal rejimlerin demokrasiye referansla kendilerini meşrulaştırma çabası içinde olmalarıdır. Finer 1962 yılı sonunda kaleme aldığı "At Sırtındaki Adam” adlı eserinde, askeri diktatörlerin bile rejimlerini süsledikleri resmi etiketlere demokrasi kelimesini eklediklerini söylemiştir. Kendi şekillendirdiği rejimi, Başkanlık Demokrasisi olarak niteleyen Nasır’n yanı sıra, Eyüp Han Temel Demokrasi, Sukarno Güdümlü Demokrasi, Franco Organik Demokrasi, Stroessner Seçici Demokrasi ve son olarak Trujillo rejimi Yeni-Demokrasi gibi kavramlarla nitelemiş, kendi yönetimlerine demokratik nitelik kazandırmak istemişlerdir. ${ }^{3}$ Artık siyaset bilimciler hangi sistemin daha iyi işlediğinden çok, hangi demokrasinin daha iyi işlediği tartışmalarına girmişler ve kendi demokratik sistemlerinin erdemlerini ön plana çıkarmaya çalışmışlardır.

Halkın kendi kendini yönetmesi ya da diğer bir tabirle ülke yönetiminde halk iradesinin ağır basması veya yönetimi oluşturan siyasilerin halk tarafından denetlenmesi anlamlarına ${ }^{4}$ gelen demokrasi rejimini Kışlalı, azınlıkta olanların haklarına saygı gösterildiği ve günü geldiğinde çoğunluğa dönüşebilme yollarının açık tutulduğu özgürlükçü bir çoğunluk yönetimi olarak tanımlamaktadır. ${ }^{5}$ Demokrasi, Crick'e göre özgürlük hatta liberalizm ya da bireycilik anlamına gelmektedir. Ona göre yasalar

1 Bernard Crick, Demokrasi, çev., Ümit Hüsrev Yolsal, Ankara: Dost Yayınevi, 2012, s.21.

2 Larry Diamond, “Is The Third Wave Over?”, Journal of Democracy, 7/3 (1996), s21.

3 Crick, Demokrasi, s.16.

4 Meydan Gazetecilik, Meydan Larousse, cilt. 3, İstanbul: 1987, s.514.

5 Ahmet Taner Kışlalı, Siyasal Sitemler, Siyasal Çatışma ve Uzlaşma, Ankara: İmge Kitapevi, 2003, s.17. 
bireyi devlete karşı korumalıdır. ${ }^{6}$ Diğer taraftan Maurice Duverger gerçek demokrasinin daha mütevazı ve daha gerçekçi bir şey olduğunu, bunun her şeyden önce, devrim sonrası Fransa’nın 1793 Kurucu Meclis’inde denildiği gibi "halk için ve halkın her kesimi için özgürlük” olarak tanımlanması gerektiğini vurgulamıştır. ${ }^{7}$ Lijphart ise bir rejimin demokratik olabilmesi için, halk bütününün arzularına cevap vermesi gerektiğine inanmaktadır. Ona göre böylesine halkın eğilimlerinin tamamına cevap verebilen bir yönetim hiçbir zaman olmamıştır ve belki de hiç olmayacaktır. ${ }^{8}$ Sartori’ye göre demokrasi, çoğunluğun egemen olduğu bir baskı rejimi değildir. Diğer bir ifadeyle, çoğunluk düşüncesinin hâkim olup, diğer düşüncelerin baskı altına alınmasının, demokrasi ile hiçbir ilişkisi yoktur. Üstelik bu azınlığın çoğunluk tarafından istibdat altına alınması anlamına gelmektedir. Demokrasi, azınlıkta kalan düşüncelerin baskı altına alınması da değildir. Diğer taraftan çoğunluk karşısında azınlıkta kalan düşünceler, çoğunluk üzerinde "bilimsel doğruluklarını", "tarihsel haklılıklarını" ya da başka benzer gerçekleri ileri sürerek, çoğunluğun yerine geçme iddiasında bulunamazlar. ${ }^{9}$ Alain Touraine, demokrasiyi "en çok sayıda bireye en büyük özgürlüğü veren, olası en büyük çeşitliliği tanıyan ve koruyan siyasal yaşam biçimi”"10 olarak tanımlamaktadır. Przeworski ise demokrasiyi siyasal partilerin seçim kaybettikleri bir sistem olarak tanımlarken seçimlerin yapıldığı, muhalefetin iktidara gelme şansının olduğu bir rejim olarak kabul etmektedir. ${ }^{11}$

Tilly’e göre demokrasi her zaman tamamlanmadan kalan ve sürekli olarak tersine çevrilme riski bulunan dinamik bir süreçtir. ${ }^{12}$ Nitekim 1989 yılında Sovyetler Birliği'nin ve Doğu Bloku’nun çökmesiyle başlayan demokrasi dalgası, konu hakkında araştırma yapan akademisyenlerin dikkatlerini, Doğu Avrupa ülkelerine yöneltmelerine neden olmuş, liberal demokrasinin küresel yükselişi de demokratikleşme çabalarına yeni bir ivme kazandırmıştır. Bugün ise demokratikleşme hareketi, Arap dünyasındaki diktatörlerin yıkılmaya başlamasıyla yeni bir sürece girmiştir.

\section{Çağdaş Demokrasinin Temel Nitelikleri}

Çağdaş demokrasinin ne tür özelliklere sahip olması gerektiği, siyaset bilimcilerce günümüzde yoğun bir şekilde tartışılmaktadır. Demokrasinin birçok uygulama biçiminin olmasına rağmen üzerinde uzlaşılabilecek niteliklerin sayısı da sınırlıdır. Bunun en önemli nedeni sosyal bilimlerde yoğun olarak yaşanan kavram kargaşaları ve demokratik rejimin uygulama aşamasında ortaya çıkan sorunlarıdır. Bu karmaşıklığa rağmen demokrasilerde bulunması gereken nitelikleri Kışlalı, şöyle sıralamaktadır: Siyasal iktidarın özgür ve genel seçimlerle oluşması, gerektiğinde siyasal

6 Crick, Demokrasi, s, 17.

7 Maurice Duverger, Siyasi Partiler, çev., Ergun Özbudun, İstanbul: Bilgi Yayınevi, 1993, s.538.

8 Arend Lijphard, Çağdaş Demokrasiler, çev., Ergun Özbudun ve Ersin Onulduran, Ankara: Yetkin Yayınları, 2002, s.112.

9 Giovanni Sartori, Demokrasi Teorisine Geri Dönüş, çev., T. Karamustafaoğlu ve M. Turhan, Ankara: Yetkin Yayınları, 1996, s.8.

10 Alain Touraine, Demokrasi Nedir?, çev., Olcay Kunal, İstanbul: Yapı Kredi Yayınları, 2011, s.25.

11 Adam Przeworski, Kapitalizm ve Sosyal Demokrasi, çev., Naim Atabağsoy, Funda Çoban, İlkay Ata ve Soner Torlak, Ankara: Phoenix, 2012, s.10.

12 Charles Tilly, Demokrasi, çev., Ebru Arıcan, Ankara: Phoenix, 2007, s.9. 
iktidarın karar ve uygulamalarını da denetleyebilen bağımsız yargı, farklı toplumsal çıkar ve görüşleri temsil eden siyasal partiler, farklı toplum kesimlerini temsil eden ve siyasal katılımı kolaylaştıran, dernekler ve sendikalar gibi kitle örgütleri, yurttaşların gelişmelerden doğru bilgi edinme haklarını sağlayacak özgür kitle iletişim araçlar1. ${ }^{13}$

Demokrasiyi bir denge ve uzlaşma rejimi olarak niteleyen Kışlalı ancak birbirlerini dengeleyebilecek güçler, uzlaşmayı zorunlu kılar demektedir. Demokrasinin olabilmesi için her şeyden önce toplumların ulusal bütünlüğünü sağlanmış olması gerekmektedir. Hiçbir toplumsal sınıfın diğerleri üzerinde kesin bir üstünlügünün bulunmadığı; toplumsal sınıflar arasındaki geçiş akışkanlığının yüksek olduğu; toplumda çoğunluğun, kitle iletişim araçlarını izleyebilecek bir eğitim düzeyine sahip olması ve insanların eşitlik, özgürlük, hoşgörü ve uzmanlaşmaya dayalı bir sistemin, ulusa egemen olması gerekmektedir. ${ }^{14}$ Dahl ise ideal demokrasiyi tanımlarken beş kritik etkenden bahsetmektedir. Ona göre;

- "Bir ülkedeki demokratik kurumlar başka bir ülkenin müdahalesine maruz kalıyorsa orada demokrasinin gelişmesi mümkün değildir”.

- "Asker ve polis güçleri, demokratik yollarla seçilmiş resmi görevlilerin tam denetimi altında olmadığı sürece demokratik siyasi kurumların gelişmesi ya da varlığını sürdürmesi mümkün değildir”.

- "Yine, demokratik siyasi kurumların, keskin farklılıklar gösteren ve çatışan aktörlerin olduğu bir ülkeden çok, kültürel açıdan yeterli derecede homojen olan bir ülkede gelişmesi ve varllğını sürdürmesi daha yüksek bir ihtimaldir”.

- "Hemen hemen bütün ülkeler er ya da geç politik, ideolojik, ekonomik, askeri, uluslararası ciddi krizler yaşarlar. Eğer demokratik sistem ayakta kalacaksa bu tür krizlerin neden olacağı zorluklarla ve karmaşayla başa çıkması gerekmektedir".

- "Demokratik bir kültürün gelişmesi piyasa ekonomisiyle yakından ilgilidir. Diğer bir deyişle demokratik kurumlar için çok elverişli olan bir durum, özel sektörün sahip olduğu yani sosyalist ya da devletçi ekonomiden ziyade kapitalist olan bir piyasa ekonomisiyle mevcuttur; fakat bu aynı zamanda bir paradoksa da neden olmaktadır. Çünkü ekonomik açıdan eşit olunan bir toplumda siyasi manada da eşitlikten söz etmek çok güçtür. Bu nedenle demokrasi ile kapitalist piyasa arasında sürekli bir gerginlik vardır. Ama diğer taraftan da kapitalist toplumun ortaya çıkardığı ekonomik büyümenin demokratik siyasi kurumları geliştirmek ve sürdürmek için çok elverişli koşullar olduklarını da göz ardı edemeyiz".

Yazara göre bu beş koşulun hepsinin de var olduğu bir ülkede demokrasinin konsolide olması ve korunması neredeyse kesindir. Bu beş koşulun tamamından mahrum 
olan bir ülkede demokrasinin pekişmesi veya korunması oldukça zordur. ${ }^{15}$

Demokrasi konusunda kafa yoran Dahl, ideal bir demokratik yönetim için bazı kriterleri ortaya koymuş; fakat bunların sağlıklı bir şekilde uygulanacağına ve sağlıklı bir demokratik süreç ve yönetimin gerçekleşeceğine inanmadığını belirtmiştir. Ona göre bu standartların ilki toplumu oluşturan üyelerin, politikanın ne olması gerektiği konusunda görüşlerini diğer üyelerin dikkatine sunan ve etkin imkânlara sahip olma anlamına gelen "etkin katılımdır". Politikanın ne olacağıyla ilgili karar verildikten sonra her üyenin oy vermek için eşit ve etkin hakka sahip olması anlamına gelen "oy kullanma eşitliğ̣” de ikinci standart olarak görülmektedir. Her üyenin ilgili alternatif politikalar ve onların sebep olduğu muhtemel sonuçlar hakkında "bilgi edinmesi", üçüncü standart olarak ileri sürülmüştür. Dördüncü standart olan "gündemin kontrolü” ise üyelerin gündeme konacak maddelerin hangilerinin olacağı konusunda karar verme haklarının olmasıdır. Dahl’ın bahsetmiş olduğu son standart ise sürece "bir ülkede sürekli olarak ikamet eden erişkinlerin" diye tabir edilen yetişkinlerin dâhil edilmesidir. ${ }^{16}$

Yine Dahl'a ilaveten günümüzde ideal demokrasiyi tanımlamada kullanılan ve hangi ülkelerin demokratik hangilerinin olmadığı konusunda uluslararası örgütlerin hazırlamış olduğu bir takım veriler de, referans kaynağı olarak dikkat çeker. Bunların içinden belki de en önemlisi New York merkezli, demokrasiyi izleme örgütü olan Freedom House olup her yıl, araştırma kapsamına aldığı devletler hakkında, sivil özgürlükler ve siyasal haklar yönünden birden yediye kadar derecelendirme yapmaktadır. Freedom House siyasal haklar bağlamında ülkeleri incelerken; adil seçimlerin yapılıp yapılmadığ ve ekonomik oligarşilerin tahakkümü altında olup olmadıkları, kültürel farklılıklara ve azınlık haklarına saygı, tartışmaya imkân tanıyan politik sistemin varlığı, toplantı ve gösteri yapma özgürlüğü, siyasi örgütlenme özgürlüğü, sendikal haklar, hukukun üstünlüğ̈̈, bağımsız yargı, kişisel özerklik, mülkiyet haklarının güvence altında olup olmadı̆̆ 1 , cinsiyet eşitliği gibi ${ }^{17}$ konuları incelemektedir.

Tilly ise demokratik rejimleri, yüksek kapasiteli demokratik olmayan, düşük kapasiteli demokratik olmayan, yüksek kapasiteli demokratik ve düşük kapasiteli demokratik olmak üzere 4 gruba ayırmaktadır. Yüksek kapasiteli demokratik olmayan yönetimde söz hakkına önem verilmeyen, devletin güvenlik güçlerine her türlü kamu politikasına girme hakkı sağlanan, yukarıdan müdahale veya alttan kitle isyanlarıyla yapılan rejim değişiklikleri uygulamaları görülmektedir. Yazar’a göre İran ve Kazakistan bu grup içerisinde yer alan ülkelerdir. Düşük kapasiteli demokratik olmayan yönetimlerin özelliği ise iç savaş gibi sıkça yaşanan şiddet içeren mücadelelerin görülmesi, siyasi aktörlerin dâhil birçok kişinin öldürücü şiddete başvurmasıdır. Somali, Kongo bu grupta yer almaktadır. Yüksek kapasiteli demokratik yönetimlerin özellikleri ise sık görülen toplumsal hareketler, çıkar grubu faaliyetleri, siyasi parti hareketlilikleri, rekabete dayalı seçimler ile devletin kamu politikalarını görece dü-

15 Robert Dahl, Demokrasi Üzerine, çev., Betül Kadığlu, Ankara: Phoenix, 2010, s.162-174.

16 Dahl, Demokrasi Üzerine, s.47-48.

17 Tilly, Demokrasi, s.16-17. 
şük düzeylerdeki politik şiddetle birleşmiş yaygın gözetimidir. Norveç ve Japonya bu grubun içinde yer almaktadır. Yine sık görülen toplumsal hareketlilik, çıkar grubu faaliyetleri ve siyasi parti hareketliliğine ek olarak daha az etkin devlet gözetimi, yarı yasal ya da yasal olmayan aktörlerin kamu politikalarına daha fazla müdahalesi ve kamu politikalarında fazla ve yüksek düzeyde öldürücü şiddet, düşük kapasiteli demokratik yönetimlerin özellikleri olup Jamaika örnek olarak verilmektedir. ${ }^{18} \mathrm{Her}$ ne kadar demokrasi farklı gruplar altında incelenip ülkeler kategorize edilerek anlamlandırılmaya çalışılsa da üzerinde durmamız gereken bir diğer husus, demokratik sistemin vesayetten arındırılmış olmasıdır. Bunun için bakılması gereken alan demokratik bir sistemde var olan sivil-asker ilişkilerinin niteliği ve etkisidir.

\section{Sivil-Asker Illişkilerine Dair Kavramsal Bir Çerçeve}

Yürütmeye bağlı ve ülke savunmasından sorumlu bir kurum olan ordu, modern demokratik ülkelerde siyasetin bir aktöründen çok kendi sınırları içerinde hareket eden bir yapı görüntüsü vermektedir. Diğer taraftan modernleşme sürecini tamamlayamamış ve bu yolda demokrasiyi yönetim biçimi olarak tercih etmiş ülkelerde ise ordu, gerek ideolojik gerekse kurumsal çıkar anlamında kendi sınırları içerisinde kalmayarak siyasette aktif bir rol üstlenebilmiş, modernleşmeye önderlik eden itici bir güç olarak siyasal ve ekonomik kararların alınmasında etkili olabilmiştir. ${ }^{19} \mathrm{Bu}$ durum ise demokrasinin tam anlamıyla istikrara kavuşamaması ya da diğer bir ifade ile pekişmemesine neden olan vesayetçi uygulamaları akla getirmektedir. Siyasi ortamda çeşitli vesayetçi uygulamalar görülmekle beraber en sık rastlananı ordu kurumunun siyasetteki hâkimiyetidir. Askerin fiili olarak güç kullandığı veya var olduğu bir toplumda bağımsız bir siyasal aktör haline geldiği, çeşitli nedenlerle askerlerin üzerindeki sivil kontrolün ortadan kalktığı veya azaldığı, siyasal sahnede hâkim siyasal güç olarak sivil siyasetçilerin değil askerin yer aldığı bu ortam "pretoryenizm" olarak telaffuz edilmekte ve daha çok yeni kurulan demokrasilerde veya demokratikleşme çabası içinde olan ülkelerde önemli bir sorun teşkil etmektedir. ${ }^{20}$

Bugün sivil-asker ilişkilerine baktığımızda Samuel Huntington, Morris Janowitz, Douglas Bland, Nordlinger, Rebecca L. Schiff ve Amos Perlmutter'i sivil-asker ilişkilerinin teorik altyapısının oluşturulmasında katkıları olan önemli akademisyenler olarak görmekteyiz. İdeal sivil-asker ilişkileri konusunda akademisyenler arasında, üzerinde uzlaşılmış bir model olmadığı gibi konu üzerinde çok sayıda farklı fikir de ortaya atılmıştır. ${ }^{21}$ Hepsinin ortak görüşü; demokrasiyi korumak için ordunun hem sivil otoritenin -hükümetin- kontrolüne tabi olması hem de profesyonel özerklik ve siyasi tarafsızlığa sahip bulunması gerektiği yönündedir. ${ }^{22}$

Huntington pretoryanizmi; oligarşik pretoryanizm, radikal pretoryanizm ve kitle

18 Tilly, Demokrasi, s.41-44.

19 Öztürk, Ordu ve Politika, s.30.

20 Birsen Örs, Türkiye’de Askeri Müdahaleler Bir Açıklama Modeli, İstanbul: Der Yayıncılık, 1996, s.3.

21 Mutlu Yıldırım, "Türkiye’de Sivil Asker İlişkileri Bağlamında 1966-1973 Cumhurbaşkanlığı Seçimleri”, Yayınlanmamış Yüksek Lisans Tezi, Pamukkale Üniversitesi, 2010, s.4.

22 Eva Etzioni-Halevy, "Civil-Military Relations and Democracy: The Case of the Military-Political Elites' Connection in Israel”, Armed Forces and Society, 22/3 (1996), s.402. 
pretoryanizmi olarak üç aşamada ele almaktadır. Oligarşik pretoryanizmde hâkim olan sınıf, büyük toprak sahipleri, din adamları ve kılıç kullananlar iken sosyal kurumlar farklılaşmamış, yönetici sınıfa mensup olanlar siyasal, askeri, dini, sosyal ve ekonomik anlamda liderlik özelliklerini aynı anda üstlenebilmektedirler. Radikal modelde ise siyasal katılma sınırlı, yönetsel etki ise yüksek düzeydedir. Siyaset orta sınıfların ortaya çıkışına hazır değildir. İlk aşamada siyaset sahnesinde aktif rol alanlar askerlerdir. Bu radikal modele Huntington 1908-1922 yıllarındaki Türkiye’yi örnek göstermektedir. Ordu içinde bulunan subaylar, kontrolü ele geçirmek için sürekli mücadele içindedir. Bu modelde ordu, siyasete tamamen siyasal nedenlerle müdahale etmekte, askeri müdahaleyi çözüm olarak görüp bunu sivil sosyal unsurlarla birlikte gerçekleştirmektedir. Kitle pretoryanizminde, ordu siyasetin üstünde ve değişimi engelleme adına hareket etmektedir. Böyle bir toplumda askerler gardiyan rolünü üstlenirken müdahalelere sebep olarak siyasal sistemdeki geçici ve olağanüstü çatlamaları gösterseler de asıl neden, siyasal sistemin kendisiyle ilişkilidir ve burada toplumun modernleşme süreci üzerinde durulmalıdır. ${ }^{23}$

Askerin sivil siyaset sahnesindeki rolü üzerinde duran Huntington, askeri gücü en aza indirme adına "sivil kontrolü” yani sivil unsurların kendi güçlerini askerî unsurlar karşısında hâkim kılması şeklinde statik bir önerme ortaya koymaktadır. Ona göre bunu gerçekleştirmenin objektif ve sübjektif sivil kontrol olmak üzere iki yolu bulunmaktadır ve her iki önermede de askerin profesyonelleşmesine vurgu vardır. Objektif sivil kontrolde amaçlanan orduyu askerileştirip devletin aracı yapmak suretiyle askerin siyasetin dışında tutulmasıdır. Subjektif sivil kontrol, siyasi ve askeri sorumlulukları bir araya getiren ve askeri işlemlerin kontrolünü tek bir yasal otoriteye veren yöntemdir. Askerin siyasete katılmasını öngörür. ${ }^{24}$

Janowitz ise Profesyonel Ordu isimli eserinde profesyonel silahlı kuvvetlerin kurumsal bir analizini yaparak, Huntington'un önermiş olduğu sivil kontrol modeli yerine farklı toplumsal koşullara göre değişiklik gösterebilen, dinamik bir profesyonelleşme önermektedir. Modern demokratik toplumlarda askeri teşkilatlarla ilgili oluşturduğu hipotezleri bu konuda daha sonra yapılacak araştırmaların temelini oluşturmuştur. ${ }^{25}$ Ona göre Huntington’ın objektif sivil kontrol kavramında tavsiye ettiği izolasyon, yani ordunun izole edilmesi, yanlış anlaşılmaya sebep olup çatışmanın kapısını aralamaktadır. Çünkü siviller ordunun yeterli donanıma sahip olmadığı alanlardaki açlımları desteklerken; ordu da kendini, savunmak için sorumlu olduğu toplumun karşısında bulmaktadır. Bu endişeler, Morris Janowitz'in sivil-asker ilişkilerindeki soruna çizdiği çerçevenin temelinde yer alır. ${ }^{26}$ Janowitz siyasi bilince sahip, sivillerle örtüşebilen subayları tercih etmektedir. ${ }^{27}$ Apolitik ve tarafsız, toplumdan göreceli olarak ayrılmış bir askerlik mesleğini öngören Huntington'un aksine Janowitz, siyasi

23 Örs, Türkiye’de Askeri Müdahaleler Bir Açıklama Modeli, s.17-24.

24 Samuel Huntington, “Civilian Control and the Constitution”, The American Political Science Review, L (1956), s.678.

25 James Burk, "Morris Janowitz and the Origins of Sociological Research", Armed Forces and Society, 19/2 (1993)

s. 168 .

26 Yıldırım, "Türkiye’de Sivil Asker İlișkileri”, s.5.

27 Burk, "Morris Janowitz and the Origins of Sociological Research", s.177. 
bilince sahip, işlev ve uzmanlıkları sivillerinkiyle örtüşen subayları kabul etmekle birlikte politikaya duyarlı ve toplumla bütünleşmiş bir ordu modelini savunmaktadir.

Pretoryanizm konusunda çalışan akademisyenlerin bir diğeri Perlmutter'dir. Ona göre, pek çok durumda siviller; sivil siyasi yapı ve kurumlar işlemediği, fraksiyonlara bölünmenin gerçekleştiği ve siyasi hareketin yönetilmesi için gerekli anayasal araçlar bulunmadığı zamanlarda siyasi destek için orduya başvururlar. ${ }^{28} \mathrm{Bu}$, pretoryanizmin temel özelliklerinden biridir ve demokratik kurumların yerleşmediği ülkelerde diğerlerine göre daha sıklıkla görülen bir durumdur. Bu toplumlarda anayasal değişiklikler ordu tarafından yapılır ve ordu sık sık yönetime müdahil olur. Ona göre iki çeşit pretoryan ordu vardır: hakem ve yönetici ordular. Hakem tipinde ordu, "koruyucu zihniyetle" askeri idare için bir zaman sınırlaması koyar ve hükümeti "kabul edilebilir" bir sivil rejime devretmek için gerekli düzenlemeleri yapar. ${ }^{29}$ Yönetici tip, iktidarı bir araç değil amaç olarak görmekte ve düzenlemelerini kalıcı olmak üzere yapmaktadır.

Nordlinger ise pretoryanizmi, sivil kontrolün zıddı olarak tarif etmiş ve askerler ile sivil hükümet arasında sivil üstünlügüun çöküşüyle sonuçlanan bir çatışma olduğu zaman ortaya çıktığını söylemiştir. ${ }^{30}$ Nordlinger, pretoryan sistemleri arabulucu, muhafız ve yönetici olarak üç aşamada ele almıştır. Ona göre arabulucular daha çok statükoyu koruma hedefinde olup etkili bir şekilde veto gücünü kullanma eğilimindedirler. Muhafızlar, yönetimi kendi ellerinde tutarak sivil yöneticilerin yapmış oldukları hataları düzeltme eğilimi sergilerken, yöneticiler siyasal hâkimiyeti kesin olarak eline geçirmiş siyasal, sosyal ve ekonomik olarak kesin değişimleri desteklemektedirler. Bu grubun siyaset müdahalesi çok sert ve yüksek düzeyde olup kalıcıdır. Özellikle "ciddi siyasal, sosyal veya ekonomik krizlerde, savaş yenilgilerinde ve prestij kayıplarında, rejimin tipi ne olursa olsun, ordunun daha etkili bir rol oynaması olasıdır". 31

Mevcut sivil-asker ilişkileri teorilerinin başlıca bulgularından birisi, orduların fiziksel ve ideolojik olarak siyasi kurumlardan ayrılmış olmaları gerektiğidir. Bunun aksi ise Rebecca L. Schiff ve Dougles Bland tarafından ortaya konmuş olan uyum teorisidir. Schiff, ordu ile siviller arasında bir ayrımdan ziyade; ordu, sivil elitler ve vatandaşlar arasında oluşturulabilecek bir ahenkten, iş birliğinden bahseder. ${ }^{32}$ Toplumun, sivil-asker ilişkisini etkilediğini ve bunu da kültür üzerinden yaptığını savunan Schiff’e göre bu üç aktörün, yani ordu, sivil elitler ve vatandaşların, oluşturduğu uyumun içerisinde ayrım söz konusu olabilir; ancak bu ayrım uyumun oluşabilmesi için şart değildir. Kurumlar ve sektörler arasında oluşacak karşılıklı diyalogun daha önemli olduğunu belirtir. Teori, ilişkiselliğe üçüncü bir boyut katarak vatandaşları da

28 Amos Perlmutter, “The Praetorian State and the Praetorian Army”, Comparative Politics, 1/3, (1969), s.382. 29 Perlmutter, “The Praetorian State and the Praetorian Army”, s.390.

30 David Albright, “Comparative Conceptualization of Civil-Military Relations”, World Politics, 32/4 (1980), s.555.

31 Juan J. Linz, Totaliter ve Otoriter Rejimler, çev., Ergun Özbudun. Ankara: Liberte Yayınları, 2008, s.183.

32 Douglas Bland, "Managing the 'Expert Problem' in Civil-Military Relations”, European Security, 8/3 (1999), s.7-9. 
çerçeveye dâhil etmesiyle diğer birçok sivil-asker ilişkisini anlatan teorilerden farkını ortaya koymaktadır. Bir başka deyişle, sivil-asker konusu kurumsal öğelerin dışına taşınarak kültürü oluşturan bireyleri de olaya dâhil eder. Askerin sivil güce destek vermesi olarak da kabul edilen bu olgu, sivil hükümetlerin yetersiz kaldığı durumlarda ordunun devreye girmesini kabul eder. İç düzenin sağlanması, doğal afetler veya polisin görev alanı içinde olup da yetersiz kaldıkları durumlarda ordu, bir aktör olarak inisiyatif alabilir, bunu da sivil yönetim ve vatandaşlar ile iş birliği içinde yerine getirebilir. Ulusların özgün tarihsel ve kültürel deneyimlerini ve çeşitli diğer sivil-asker ilişkileri olasılıklarını da göz önüne alarak farklı bir alternatifi ortaya serer. Mevcut teoriler, sivil ve askeri kurumların birbirinden ayrılmasını savunurken uyum teorisi bir ulusun kültürüyle ilgili konulara işaret ederek kurumsal analizin ötesine geçmeye çalışır. Uyum teorisi yukarıda bahsedilen belirli kurumsal ve kültürel göstergeleri işler; ordu, hükümet ve toplumun iç politikaya askeri müdahaleyi engellemek amacıyla üzerinde anlaşacakları ayrı olsun, bütünleşmiş olsun, sivil-asker ilişkileri biçimlerinin oluştuğu ampirik koşulları açıklar. ${ }^{33}$

Bland ise daha çok kurumlar arası uyumdan söz etmektedir ki bu da demokrasinin gelişmişliğiyle paralellik arz eder. Demokrasi konusunda ciddi mesafeler almış çoğu Batılı ülkelerde sözü geçen kurumsal uyum gözlenebilmektedir. Özellikle uluslararası konjonktür gereği asker ile sivil unsurlar birlikte hareket edebilmektedir. Bir başka uyum da kurumlar arası değil yöneticiler arası uyumdur ve hemen hemen her ülkede görülme olasılığı vardır. Demokrasi kültürünün yerleşmiş olduğu ülkelerde çok fazla ağırlığı olmamakla birlikte atılması gereken önemli adımlarda bu uyuma ihtiyaç vardır. ${ }^{34}$ ABD’nin Körfez Savaşını yürüten komutan olan Colin Powel, daha sonraki hükümette Savunma Bakanı olarak Başkana en yakın biri durumuna gelip ABD dış politikasında söz sahibi olabilmiştir. Diğer taraftan demokrasi bağlamında daha alması gereken epey mesafe bulunan ülkelerde de benzer durumlara şahit olabilmekteyiz. Yalnız buradaki temel fark, ortak politika belirlemekten çok askerin sivil otoriteye tabi kılınmasını sağlamaktır. Mevcut sivil-asker ilişkileri teorileri, sivil ve askeri kurumların ayrışmasına ve iç politikaya askeri müdahalenin önlenmesi için sivil alanın hâkim olmasına vurgu yaparlar. Bunun tersine uyum teorisi, ordu, siyasi seçkinler ve toplum arasında diyalog, değer ve amaçların paylaşımı konularına ağırlık verir.

Askerin asli görevinin dışına çıkarak kuvvet kullanması ve bunun sonucunda siyasi hayata müdahale etmesi, siyasal karar alma mekanizmalarına dâhil olması "askeri darbe" olarak nitelendirilmektedir.

Tüm Latin Amerika ülkeleri, bazı Arap ülkeleri, birçok Afrika ve Güneydoğu Asya ülkeleri ile bazı Akdeniz ülkeleri, yaşadıkları darbe ve karşı darbe girişimleriyle sivil-asker ilişkileri bakımından olumsuz örneklere sahne olmuştur. Bu girişimler salt ordunun sivil iktidarın yerini alması şeklinde ortaya çıkarken bazen de iktidara do-

33 Rebecca Schiff, "Civil-Military Relations Reconsidered: A Theory Of Concordance”, Armed Forces \& Society, 22/1 (1995), s.10.

34 Bland, "Managing the 'Expert Problem’ in Civil-Military Relations”, s.10-11. 
laylı olarak müdahalesi şeklinde olmaktadır. ${ }^{35}$ Huntington Üçüncü Demokrasi Dalgası eserinde askerî müdahaleleri, demokrasiye karşı girişilen ters dalgalar olarak adlandırmıştır. Bu müdahalelerin ilki 1922-1942 yılları arasında görülmüş olup Roma yürüyüşü ve Mussolini'nin zayıf ve hayli yozlaşmış İtalyan demokrasisinin kolayca çözülmesiyle başlamış; akabinde Polonya, Estonya ve Letonyada siyasi çöküşler gerçekleşmiştir. İkincisi ters dalga ise 1958-1975 yılları arasında yaşanan olaylar sonucunda başta Peru olmak üzere Brezilya ve Bolivyàda yaşanmış, sivil hükümetler askerler tarafından devrilmiş ${ }^{36}$ ve yerlerine askeri rejim hükümetleri ikame edilmiştir.

Finer, askeri rejimleri, hükümetin silahlı kuvvetlerin eline geçtiği rejimler ya da silahlı kuvvetlerin emirleriyle hareket eden yapılar olarak ifade ederken ${ }^{37}$ Atay ise bu rejimleri genellikle siyasi bağımsızlıklarını yeni kazanmış, demokratik unsurların kök salmadığı az gelişmiş ülkelerde görülen, siyasal iktidarın tamamen askeri idarenin kontrolü altında bulunduğu, burjuvazinin genel çıkarlarına uygun hareket eden ve kendi meşruiyetini devrilen yönetimin olumsuz uygulamalarına bağlayıp hedeflerini anayasal ve yasal düzenlemelerle destekleyen plebisiter oylamayla meşrulaştıran rejimler olarak tanımlamaktadır. ${ }^{38}$

Varol ise askeri darbeleri genel olarak anti-demokratik bir uygulama olarak zikretse de bazen de demokratik sonuçlar doğurabileceğine dikkat çekerek açıkça demokrasiyle çelişen bir düşünceyi ortaya koymaktadır. Darbelerin daha çok otoriter ve totaliter rejimlere karşı gerçekleştiğine değinen Varol, darbeleri genel anlamda demokratik olanlar ${ }^{39}$ ile olmayanlar olarak ikiye ayırmakta, darbe eyleminden demokratik sonuç uman bir yanılgı içine düşmektedir. Ona göre demokratik olmayan askeri darbelerde sonuç siyasal rejim anlamında değişmezken, değişen tek şey liderler olmaktadır. Oysa demokratik darbelerde hem otoriter veya totaliter rejim yerini demokratik sisteme bırakır hem de liderliğe daha demokratik kişiler gelmektedir. Bu bağlamda 1974 Portekiz, 1960 Türkiye ve 2011 Misır askeri müdahalelerini demokratik sonuçlar doğuran darbeler olarak nitelemektedir. ${ }^{40}$

Askeri müdahaleler ve akabinde ortaya çıkan askeri rejimlerin nedenleri konusunda Ünsaldı, siyasi istikrarsızlıklara ve toplumsal değişimlere vurgu yapmaktadır. ${ }^{41}$ Ona göre ordunun siyasete müdahalesi her ülke için aynı değildir. Farklı toplumlarda farklı zamanlarda görülen askeri müdahalelerin nedenleri de farklı olabilmektedir. Modernleşmenin neden olduğu hızlı ve planlı olmayan ani sosyal değişimler, siyasal katılma talebini yükseltecek, bu talep baskısı ise siyasal sistemin demokratik arzında sorun yaşamasına neden olacaktır. Nitekim Huntington geleneksel yapılardan mo-

35 Örs, Türkiye’de Askeri Müdahaleler Bir Açıklama Modeli, s.7.

36 Samuel Huntington, Üçüncü Dalga 20.yy. Sonlarında Demokratlaşma, çev., Ergun Özbudun, Ankara: Türk Demokrasi Vakfı Yayınları, 2007, s.11.

37 Samuel E. Finer, The Man on Horseback: The Role of Military in Politics, Middlesex: Penguin Books, 1975, s. 164 .

38 Agâh Sabri Atay, Çok Partili Dönemde Türkiye'de Ordunun Siyasal Rolü ve Devlet Yapısı İçindeki Yeri, İstanbul: Anadolu Üniversitesi Yayınları, 1998, s.48-49.

39 Demokratik askeri darbelerin özellikleri hakkından bkz. Ozan O. Varol, "The Democratic Coup d'Êtat", Harvard International Law Journal, 53/2 (2012), s.292-356.

40 Varol, “The Democratic Coup d'Êtat", s.289, 299, 294.

41 Levent Ünsaldı, Türkiye’de Asker ve Siyaset, İstanbul: Kitap Yayınc1lı, 2008, s.259. 
dern yapılara geçişte bir çalkantı yaşanacağı, bunun da bozulmaya sebep olacağı varsayımından yola çıarak, bizatihi modernleşme sürecinin (kitle iletişim araçlarının yaygınlaşması, okur-yazar oranında artışı, kentleşme, sanayileşme, pazar ekonomisi) bile askeri müdahaleye sebep olabileceği endişesini paylaşmaktadır. ${ }^{42} \mathrm{Bu}$ ise bozulma ile sonuçlanacak, ordunun siyasete dolaylı ve dolaysız yoldan müdahalelerine uygun ortam teşkil edecektir.

Finere göre, ordunun siyasal hayata farklı yöntemlerle ve değiş̧ik derecelere varan müdahale biçimleri bulunmaktadır. Bu müdahale biçimlerinin başında "etkileme" veya "tavsiye etme" biçiminde ifade edilen ve normal anayasal kurallardan yola çıkarak gerçekleşen etkiler yer almaktadır. Bu yöntem ordunun müdahale yöntemlerinden en hafif olanıdır ve bunun mevcut pozitif hukuk kurallarına aykırı bir yönü yoktur. Ordunun ikinci müdahale biçimi ise "şantaj" biçiminde kendini göstermektedir. Sivil otoritenin gözünü korkutma, sivillerle iş birliği yapmayı reddetme ve şiddet kullanma bu yöntemin temel özelliklerini ifade eder. Üçüncüsü ise "siyasal iktidarı değiştirme" veya onun "yerini alma" biçiminde gerçekleşir ve bu aşamada sivillere karşı açıkça zor ve şiddet kullanılabilir. ${ }^{43}$

Demokratik bir sistem modelinde askerin yönetim üzerindeki etkisi ülkenin siyasi kültürü ile doğrudan ilişkilidir. Nitekim, siyasi kültür pek çok ülkenin sorunlarını anlamada ve çözümünde bir referans noktası alınmaktadır. Bu kavram toplumsal değişmeyi, sisteme yönelen desteği, bireylerin siyasal sistemle ilişki kurma biçimlerini anlamakta, siyasa yapma ve uygulama yollarını tespit etmekte önemli sonuçlar vermiştir. Siyasi kültürü siyasal tutumların, duyguların, bilgi ve becerilerin toplum içinde belirli bir biçimde dağılımı, siyasal yönelimler ve sisteme yönelik tutumlar olarak tarif eden Almond ve Verba, bu kültürü aynı zamanda askerin siyasete müdahale etmesi konusunda etkili olan çevresel faktörlerden birisi olarak görerek, toplumun gelişmişlik düzeyiyle ilişkili olduğunu ortaya koymuşlardır. Toplumları üç temel kategoride irdeleyen Almond ve Verba, 'dar görüşlü, cemaatçi' (Parochial) diye tanımladıkları ilk grupta toplumları henüz modernleşememiş, dolayısıyla siyasal aktör ve kurumların henüz tam anlamıyla oluşmadığı ve kurumsallaşamadığı ilkel cemaatler olarak nitelendirmişlerdir. 'Tebaa' (Subject) adı verilen ikinci grup toplumlarda ise siyasal hayat ve aktörler kurumsallaşmış olmasına rağmen, bu kurumsallaşma demokrasi yönünde olmamış ve halk karar alma sürecinden dışlanan pasif bir kitle haline getirilmiştir. 'Katılımcı' (Participant) adını verdikleri Batı tipi toplumlar ise demokrasinin ve demokratik sivil kültürünün davranışsal ve tutumsal olarak halka yerleştiği ve demokrasinin şehirdeki tek oyun olarak benimsendiği ülkeleri anlatır. ${ }^{44}$

Finer askerlerin siyasal hayata müdahalelerinin kapsam ve biçimi, içinde bulunduğu ülkenin siyasal kültür düzeyi ile yakından ilişkilidir demektedir. ${ }^{45}$ Köklü katılımcı demokratik siyasal kültüre sahip toplumlarda askeri güçlerin sivil yönetimlere

42 Örs, Türkiye’de Askeri Müdahaleler Bir Açıklama Modeli, s.61-63.

43 Finer, The Man on Horseback, s.163-133.

44_Gabriel Almond ve Sidney Verba, “Civic Culture”, bkz. http://academic.regis.edu/jriley/205civiculture (erişim 4 Şubat, 2015).

45 Finer, The Man on Horseback, s.108-126. 
müdahalesi tavsiye sınırını aşmazken, daha düşük siyasal kültüre sahip toplumlarda bu durum şantaj, sivil iktidarı değiştirme denemeleri ve hatta iktidarı doğrudan ele geçirmeye kadar varabilmektedir. Siyasal kültür düzeyinin zayıf olduğu ülkelerde, askeri müdahalelere karşı gelişmiş yerleşik siyasal kurumlar ile güçlü ve bilinçli sivil toplum görülmemektedir. Halkın siyasal kurumlara bağlılık düzeyi düşük olmakla birlikte toplumsal örgütlenme gelişmemiş ya da gelişmesi yasaklarla engellenmiştir. Siyasal iktidar değişiklikleri tecrübe edilmemiş, iktidara karşı oluşması beklenen muhalefet anlayışı gelişmemiştir. Ordu, şiddet veya tehdit ile sivil yönetimi istediği şekilde değiştirmekte veya sivil rejimi tamamen ortadan kaldırabilmektedir. Bu uygulamaları da halk tarafından meşru kabul edilip tepki verilmemektedir. ${ }^{46}$

Halkın kişiler üstü amaçlar veya ortak çıkarlar uğruna kendi çıkarlarından feragat etmesi de zayıf siyasal kültürün özelliği olup, siyasette hiyerarşiye ve katılığa sebep olmaktadır. Bu özellik dış tehlikelere karşı ulusu korumakta yarar sağlarken demokrasinin işleyişini zorlaştırmaktadır. Ortak menfaatler amacıyla yapılan askeri müdahalede halkın desteğinin alınmasını kolaylaştırmaktadır. Önemli olan ulusun birliği ve bütünlügüdür, söz konusu bu olunca kişisel ve grupsal çıkarlar önemli olmaktan çıkmaktadır. Çünkü devlet her türlü bireysel çıkarın üstündedir ve tüm toplumun kolektif çıkar ve amaçlarını temsil etmektedir. Devletin çıkarlarını korumak aynı zamanda toplumun da çıkarlarını korumak demektir. Bu da seçkinci zümrelerin işini gerek gündelik siyasete katılmak bakımından gerekse askeri müdahalede bulunmak açısından kolaylaştırmaktadır.

Finer ordunun müdahale düzeyi ile toplumun siyasal kültür düzeyini dört grupta toplamaktadır. Bunlardan ilki İsveç, Kanada, Avustralya, Yeni Zelanda ve Hollanda gibi ülkelerde görülen “olgunlaşmış siyasal kültür”dür. İkincisi gelişmiş siyasal kültür olup Hitler dönemine kadar Almanya, iki savaş arası Japonya, III. Cumhuriyet’ten itibaren Fransa ve SSCB örnek gösterilmektedir. Bu gibi toplumlarda sivil kurumlar oldukça gelişmiş, askeri müdahalelere karşı güçlü bir direniş vardır. Diğer siyasal kültür ise "zayıf siyasal kültürdür". Türkiye, Arjantin ve İspanya zayıf kültür ile gelişmiş siyasal kültür arasında, Mısır, Suriye, Pakistan, Irak ve Sudan zayıf siyasal kültürün altında yer almıştır. ${ }^{47}$ İkinci grubun sivil toplum örgütlenmesi oldukça zayıftır. Askeri müdahalelere karşı gelişmiş ülkelerdeki gibi güçlü bir direniş yoktur. Kamuoyu zayıf ve yer yer kendi içinde bölünmüş durumdadır. Dördüncü kültür tipi ise Meksika, Arjantin, Haiti ve Paraguay'ın tecrübe etmiş olduğu ve kamuoyunun pek dikkate alınmadığ "minimal siyasal kültür" olarak adlandırılmaktadır.

Toplumsal yapı ve özellikleri de siyasi kültürün içinde en önemli unsurlarından biri olarak askeri müdahalelerde etkin bir rol oynamaktadır. Toplumun gelişmesiyle ortaya çıkan daha girift yapılar, askerin siyasete dolaylı veya direkt olarak müdahalesini engellemektedir. Tersi durumlar için Örs, "görece olarak daha az karmaşık ve farklılaşmamış bir toplumda daha homojen, disiplinli ve uyumlu bir grup olan ordu,

46 Finer’e göre Arjantin, İspanya, Yunanistan ve Türkiye siyasal kültür düzeyi zayıf olan ülkeler olmalarına rağmen günümüzde siyasetin temel prensiplerinin işlediği ülkeler arasında yer almaktadırlar, bkz. Finer, The Man on Horseback, s.108-126.

47 Örs, Türkiye’de Askeri Müdahaleler Bir Açıklama Modeli, s.45-46. 
etkili bir biçimde siyasal liderlik rolünü oynayabilmektedir” demektedir. ${ }^{48}$ Nitekim birçok geri kalmış ve siyasi çalkantılar içinde boğuşan toplumlarda söz konusu askeri yönetimleri görmek hiç de şaşırtıcı değildir. Turhan da az gelişmiş ülkelerin toplumsal yapılarında toplumsal güçsüzlüğün egemen olması ve bu ortamda en iyi örgütlenmiş ve en etkili gücün orduda bulunmasını müdahalenin nedeni olarak görmektedir. ${ }^{49}$ Toplumun görece karmaşık ve örgütsüz bir tabiata sahip olması, orduyu özerk bir güç haline getirmektedir. Buna karşın siyasal katılım yaygınlaşıp toplum daha karmaşık hale gelince, askeri müdahalenin gerçekleşme ihtimali azalmaktadır. Karmaşık, gelişen ve aynı zamanda çeşitlenen toplum, askere karşı kendi argümanlarını geliştirmeye başlar; bu da bir darbe durumunda askerin kullanacağı gücü daha acımasız hale getirir. Çünkü karşısında daha organize olmuş bir grup durmaktadır.

Bugün demokrasi konusunda önemli mesafeler almış gelişmiş ülkeler, farklı sivil-asker ilişkilerine sahip örnekleriyle karşımızda durmaktadır. Her biri kendine has farklı modellere sahipsede ortak noktaları nihayi demokrasiye ulaşma hedefinden vazgeçmemiş olmaları, dahası bu çaba için çağın gereklerine uygun hareket etmeleridir. Farklı sivil-asker ilişkileri modellerine sahip gelişmiş ülkelerin yüksek demokrasi standartlarına sahip olmaları o ülkelerin siyasi kültür düzeyi ile yakından ilişkilidir.

\section{Gelişmiş Ülkelerde Ordu Tecrübesi}

1950-2010 tarihleri arasında dünyadaki askeri müdahaleleri irdeleyen Powell ve Thyne, 457 tespitle askeri müdahaleler konusunda çarpıcı bir gerçeği ortaya koymuşlardir. Bu darbelerin 12 tanesi Avrupa'da, 72 tanesi Ortadoğu’da, 59 tanesi Asya'da, 169 tanesi Afrika'da ve 145 tanesi Latin Amerika'da gerçekleşmiş, yapılan müdahaleler \% 46,96 ortalama ile başarıyla sonuçlanmıştır. ${ }^{50} \mathrm{Bu}$ tablodan da anlaşılacağ gibi gelişmiş ülkelerin yer aldığ 1 bölgelerde sivil-asker ilişkileri durağan seyretmekte, askeri müdahalelere pek rastlanmamaktadır. Sanayileşmesini tamamlamış bu ülkelerde silahlı kuvvetler, tamamen siyasi otoritenin buyruğu altında olup ${ }^{51}$ "doğrudan doğruya siyasete karışmayarak ulusal bir çıkar anlayışının bekçiliğini yapmaktadır”. ${ }^{52} \mathrm{Bu}$ durum ilk olarak bu ülkelerin sosyal ve ekonomik gelişmişlik düzeyi ve zengin demokratik siyasal kültürleri ile açıklanabilir. İkincisi bu biçimdeki bir sonuç gelişmiş ülkelerdeki silahlı kuvvetlerin etkisinin ülkelerin ekonomik yönüyle yakından ilgili olduğunu da ortaya koymaktadır.

Siyasal kültür düzeyi bakımından olgunlaşan, kurumsal yapısı yerleşip düzene giren ve tüm kamusal kurumların rol ve sorumlulukları herkes tarafından benimsenen ülkelerde siyasal sistemin işleyişi de kolay olacağından, askerlerin siyasal hayata doğrudan müdahale etme olasılığı da azalmaktadır. Bu ülkelerdeki silahlı kuvvetlerin siyasal hayata etkisi, hukuki düzenin dışına çıkamayacak biçimde mevcut kurallar çerçevesinde gerçekleşmekte, "etkili olduğu alanlar daha çok diş politika ve ülke sa-

48 Örs, Türkiye’de Askeri Müdahaleler Bir Açıklama Modeli, s.23.

49 Mehmet Turhan, Siyasal Elitler, Ankara: Gündoğan Yayınları, 2000, s.193.

50 Jonattan M. Powell ve Clayton. L. Thyne, "Global Instances of Coups from 1950 to 2010: A New Dataset", Journal of Peace Research, 48 (2), 2011, s. 255.

51 Öztürk, Ordu ve Politika, s. 50.

52 Gül Tuba Dağc1, Osmanlidan Günümüze Ordu ve Siyaset İlişkisi, İstanbul: İlgi Yayınları, 2006, s.22. 
vunmasıyla" ${ }^{33}$ sınırlı kalmaktadır. Asker tamamen sivil idarenin kontrolünde olduğu için de yasa ve kanunlarda askerin "çıkış güvenceleri" bağlamında, ayrıcalıklı bir konumda yer aldığını gösteren hükümlere yer verme gereği duyulmamıştır. Çünkü siyasal ve ekonomik anlamda gelişmiş tüm demokratik ülkelerde askeri konularla ilgili milli güvenlik politikalarının uygulanması ve kontrolü, yürütmenin elindedir. Sadece askeri harcamalarda askeri temsilciler siyasiler ile istişare görevini yerine getirmektedirler. İcra organı parlamenter rejimlerde söz konusu politikaların yürütülmesinde yasama organına karşı sorumludur ve siyasal yönü kuvvetli olan bu erk de anayasa ve kanunların izin verdiği ölçüde, hükümet politikasını belirleyip uygulama yetkisini kullanmaktadır. Tipkı milli eğitim, sağlık, ekonomi konularında olduğu gibi milli güvenliği ilgilendiren askeri konularda da tek sorumlu mercii yürütme organıdır. Aşağıda demokrasi ve sivil irade üstünlügünü benimseyen ülkelerden ABD, İngiltere, Fransa, İspanya ve Yunanistan ile kendine has karakteristik demokratik yönetim modeliyle İsrail'i ve militarizmi gelişmekte model almış olan Almanya ve Japonya örneklerini sivil-asker ilişkileri özelinde irdelemeye çalışacağız.

Bunların en başında mevcut dünya düzeninin en etkili aktörü, ABD’dir. ABD’nin bu konumu hakkında farklı düşünceler ortaya konmuş olsa da kesin olan bir şey var ki o da bu ülkenin dünyaya hâkim bir güç haline gelmesinde ordunun önemli bir role sahip olmasıdır. Sivil-asker ilişkileri konusunda başvurulan ve düşünceleriyle bu alana yol gösteren Huntington’a göre ABD'deki sivil-asker ilişkileri, askerî realizm ve sivil liberalizm fikrine dayanmaktadır. Ordunun sivil idareye tabi olması ise savaşçı rolün dış dünyaya dönük olmasından kaynaklanmaktadır. Yani daha çok dış politika ve dış unsurlarla hem hal olan ABD ordusu, ülkenin iç siyasetini etkileyecek bir çaba içerisinde değildir. Bu da onun tamamen sivil siyasetin kontrolünde olmasını sağlamaktadır. ${ }^{54}$ Ordunun siyasetteki konumu ve etki alanları, sivil siyasetçiler tarafından bugün dahi tartışılan en temel konuların başında gelmektedir. Cumhuriyetçi kanadı temsil eden siyasetçiler, ordunun dış müdahalelerde kullanılmasını ülke güvenliği açısından elzem görürken, Demokratlar, ordunun dış müdahalelerde kullanılmasını ülke ekonomisini olumsuz etkilediği ve Amerikan halkının menfaatlerine uymadığı gerekçesiyle karşı çıkmaktadırlar. Bu durum ordu mensuplarını da etkilemiştir. Özellikle İkinci Dünya Savaşı sonrasında Amerikan askerlerini ülke dışında kullanıp kullanmama konusunda devlet adamları ve askerlerin davranışlarını inceleyen Betts, askeri danışmanların genellikle kendi içlerinde bölünmüş olduklarını ve tavsiyelerinin sivil siyasetçilerden farklı olması gerekirken onlarla benzer tutumlara sahip olduklarını gözlemlemiştir. ${ }^{55}$ Yani bir bakıma ordu, kendi önerilerini sunup sivil siyasetçilere alternatif olma seçeneğini kullanıp hakem rolünü oynamak yerine siyasetçiler gibi bölünmüş durumdadır. Bu durum bir yandan ordunun siyasileştiği ve ulusal güvenlik bağlamında zaafa düşmüş olduğu izlenimini yaratırken diğer taraftan da Huntington’un bahsetmiş olduğu sivil kontrol prensibinin de bir zaferi olarak değerlendirilebilmektedir.

53 George A. Kelly, “The Global Civil-Military Dilamma”, The Review of Politics, 25/3 (1963), s.296.

54 Burk, "Morris Janowitz and the Origins of Sociological Research", s.457.

55 William O. Chittick, “The Politicization of Security Policy”, The Journal of Politics, 50/1 (1988), s.181. 
Desch'e göre meşruiyet noktasını insani nedenlere ve dünya barışını korumaya bağlayan dışa yönelmiş bir ordu, devletin sahip olduğu dış misyonları sürdürerek gerekli kaynakları sağlıyorsa iç politikaya karışma ihtiyacı duymayacaktır. Yani ordunun diş işlerle uğraşması ve dış mücadelelerde kullanılması sivil kontrolü hâkim kılacaktır. Tersine hem dış hem de iç tehditler önemsiz boyutlarda cereyan ediyorsa o zaman sivil kontrol zayıflayacak ve bazı durumlarda askeri öncelikler ön plana çıkacaktır. O nedenle dışa yönelik askeri doktrinler, sivil kontrol için en uygun olandır. İçe yönelik olanlar ise sivil kontrolü sarsar ki bu da Amerikan demokrasisini olumsuz yönde etkiler. ${ }^{56}$

ABD’nin en karakteristik yönünü oluşturan kökleşmiş demokrasi tecrübesi, sivil kontrol ve sivil üstünlük ilkeleri, dünya üzerindeki hâkim güç konumunda yer alan Amerikan ordusunu da etkilemiş, yalnızca anayasanın yapısal özelliklerinden biri olarak değil, ahlaki bir ihtiyaç olarak da kabul edilmiştir. Bu belki de böyle olduğu için Körfez Savaşı’nın Genelkurmay Başkanı Colin Powell hiçbir endişe duyulmayarak Bush yönetimi tarafından Savunma Bakanlığı’na getirilebilmiştir.

İngiltere ise diğer Avrupa ülkeleriyle benzerlik gösterse de kendine özgü siyasi tarihi, geçmişi ve yazılı olmayan bir anayasa tarafından yönetilmesi, demokrasinin beşiği etiketinin yakıştırılmasına rağmen tecrübe etmiş olduğu sivil-asker ilişkileri, onu diğer Avrupa devletlerinden ayırmaktadır. İngiltere büyük bir iç savaştan sonra 17. yüzyıl sonu 18. yüzyılın başlarında şartların da uygun olmasıyla ülke içinde var olan gerilimi sona erdirebilmiş, uzlaşma çabası gösterebilmiştir. Arkasından başlayan restorasyon döneminde bu uzlaşı çabası sonuç vermiştir. ${ }^{57}$ Fakat sonrasında 1900'lü yılların başında yaşanan Kuzey sorunu İngiltere’nin güvenlik algısını revize etmesine neden olmuştur.

Konu hakkında Christopher Dandeker İngiltere’nin ulusal güvenlik algısını Kuzey İrlanda sorunu, İngiltere’nin ulusal güvenliğinin gelişmesini tetikleyen bir iç sorun, Soğuk Savaş süreci boyunca ortaya çıkan nükleer tehlike, kargaşa ve tahribat ortamı ile güvenlik devleti algısında önem verilen gizlilik politikası şeklinde özetlemektedir. ${ }^{58}$ Özellikle II. Dünya Savaşı sonrasında yaşanan Soğuk Savaş dönemi ve Kuzey İrlanda'daki ayrılıkçı İrlanda Cumhuriyet Ordusu (IRA) örgütünün sürdürmüş olduğu terör faaliyetleri İngiltere’de güvenlik devletinin oluşmasını sağlamakla kalmamış, aynı zamanda güvenlik devleti kontrol ağının daha da genişlemesine sebebiyet vermiştir. Nitekim Soğuk Savaşın etkileri uzun bir döneme yayılmış, sivil-asker ilişkileri sorunsalının bugünlere gelmesinde etkili olmuştur. Keza güvenlik devletinin varlık nedenini oluşturan Soğuk Savaş dönemi ve ortaya çıkan nükleer silahlanma süreci akabinde, 1960 ve 1970’li yıllarda gündeme gelen profesyonel ordu kavramı da, güvenlik devleti anlayışının devamını sağlamakla kalmamış, ordunun devamlı savaşa hazır bir yapı olarak durmasına neden olmuştur. ${ }^{59}$ Diğer yandan Birleşik Krallığın

56 Michael Desch, "Soldiers, States, and Structures: The End of the Cold War and Weakening U.S. Civilian Control" Armed Forces and Society, 24/3 (1998), s.396.

57 Murat Belge, Militarist Modernleşme, İstanbul: İletişim Yayınları, 2011, s.39.

58 Christopher Dandeker, “The Military in Democratic Societies”, Society, 38/6 (2001), s.362.

59 Dandeker, “The Military in Democratic Societies”, s.360. 
kendine has iç sorunları da bahsi geçen güvenlik devleti olgusunu canlı tutmuştur. Özellikle Kuzey İrlanda'da yaşanan ve iç huzuru tehdit eden terör eylemleri bir taraftan güvenlik algısını diri tutarken, diğer taraftan temel hak ve özgürlüklerin kısıtlanmasina gerekçe olarak gösterilmiştir.

Monarşi ve Lordlar Kamarası gibi bugün demokratik görünmeyen kurumlara sahip olmasına rağmen, demokratik siyaset kültürün toplumca özümsenmiş olmasından dolayı İngiltere, sivil-asker ilişkileri bağlamında kayda değer bir krizle karşı karşıya kalmamıştır ${ }^{60}$, sivil otoritenin itibarını sarsacak bir olay vuku bulmamıştır. Kuzey İrlanda'da meydana gelen terör eylemlerine rağmen İngiltere'de sivil unsur hâkimiyetini başarıyla sürdürebilmiştir. Bunda güçlü ve bağımsız bir parlamento, ticari ve endüstri çevrelerin varlığı ile ciddi bir köylü sorununun olmaması önemli etkenler olarak göze çarpmaktadır. 19. yüzyılda hızla gelişen kapitalizm ve toprak sahibi üst sınıfların varlığı demokrasinin gelişmesinde etkili olmuştur. ${ }^{61} \mathrm{Bu}$ süreçte ordunun militarist bir geçmişe sahip olmamasının da payı büyüktür. İngiliz toplumu da bu paya katkı sağlamıştır; zira toplum, ordunun kendi sınırları içerisinde var olmasını istemiş ve ordu dışında her hangi bir yerde askeri bir ideolojinin var olmasını ve bunun kışla dışına taşınmasını kabul etmemiştir. ${ }^{62}$

Sivil-asker ilişkilerinde demokrasi bağlamında gelişmiş bir diğer ülke Fransa’dır. V. Cumhuriyet'ten itibaren Fransa'da sivil kontrol diğer ülkelere göre daha başarılı ilerlemiş, ordunun sivil iradeye olan bağlllı̆̆ında sorun kalmamıştır. Bunda Fransảnın tecrübe etmiş olduğu beş Cumhuriyetteki ordunun tutumu etkili olmuştur. Zira savunma mekanizmalarının en küçük düzeyde bile kullanımı siyasi yetkililere bırakılmıştır. Diğer devletlerle ortaya çıkan sorunların çözümü veya askeri kararlardaki caydırıcılık düşüncesi de sivil inisiyatife bırakılmıştır. Bu durum Fransảnın dış siyasetine bakıldığında çok rahat fark edilmektedir. Artık Fransa savunması iki ayaktan oluşmaktadır. Bunlardan birincisi Kuzey Atlantik Antlaşması Örgütü (NATO) müttefikleriyle iş birliği olan uluslararası ayak, ikincisi de kendi nükleer güçleri ve askeri endüstri yapısını da içine alan ulusal bağımsızlık ayağı. Fransa bunu üç yolla yerine getirmektedir. Bunlardan ilki Fransảnın nükleer güçlerinin koruduğu ulusal sığınak, ikincisi Avrupa’daki sorumluluklar ve son olarak Afrika ve diğer uzak bölgelerdeki çıkarlarını kapsayan denizaşırı boyuttur. ${ }^{63}$

Savunma konusu dâhil Fransa'da sahip olunan gelenek, vatandaşa karşı sorumlu olanların yani sivil siyasetçilerin gereken riskleri almasına dayalıdır. Bu durum ise seçilmişlerin üzerine büyük bir sorumluluk yüklemektedir. Fransız Devrimi’ni gerçekleştirmiş ve halk yönetimi idealinin yayılmasına öncülük etmiş olan Fransız siyasetçiler, askeri konularda da yetkiyi ellerinde tutmayı başarabilmişlerdir. Tabiî bunda Fransız toplumunun özgürlüklere olan bağlll lı̆̆ ve her türlü militarizme karşı olan şiddetli karşı duruşunun da payı büyüktür. Bu aynı zamanda siyasal, toplum-

60 Belge, Militarist Modernleşme, s.39.

61 Barrington Moore, Diktatörlüğün ve Demokrasinin Toplumsal Kökenleri, çev., Şirin Tekeli ve Alaeddin Şenel, Ankara: İmge Kitapevi, 2012, s.69-70.

62 Belge, Militarist Modernleșme, s.48.

63 David Yost, "France in the New Europe”, Foreign Affairs, 69/5 (1991), s.257. 
sal sivil üstünlük kültürünün de bir sonucudur. Diğer taraftan ordu yurt dışı alanlarda kullanılmamış değildir. Nitekim özellikle eski sömürge alanlarında ne zaman bir problem yaşansa Fransa müdahalede bulunmaktan çekinmemiş, 1960 yılından bugüne, yaklaşık 30 müdahale gerçekleştirmiştir. Libya'ya yapılan son askeri müdahale bunun canlı örneğidir. Bu orduyu çok önemli bir politik araç haline getirmiştir. ${ }^{64}$ Ordu özellikle dış politikada aktif olarak kullanılsa dâhi sivil kontrol prensiplerinden uzaklaşılmamıştır. Ordunun tekelinde olan teknik konular bile Fransız siyasetinin kontrolü altındadır. Bu durum ise ordunun yetki alanını diğer ülkelerle kıyasla oldukça daraltmıştır. ${ }^{65}$ Fransız siyasetinin askeri konularındaki bu hâkimiyeti kendi yönetim sisteminden kaynaklanmaktadır. Uygulanmakta olan yarı-başkanlık sisteminde cumhurbaşkanının halk tarafından seçilmesi, diğer demokrasilerle karşılaştırıldığında cumhurbaşkanının oldukça geniş yetkilere sahip olmasını sağlayarak meclis gücünün de üstünde yer alması anlamına gelmektedir.

Gerek Fransa ve İngiltere gerekse ABD, burjuvazinin devrim yaparak iktidar olduğu üç ülkedir ve bu devrimler burjuva devrimlerinin birer örneğidir. Bunların başlica özelliği burjuva sınıfının böyle zor bir işi başarabilecek kadar gelişmiş ve güçlü olmasıdır. Bu güce kendileri ulaştıkları için devrim sonrası kurdukları rejimlerde de ipleri ellerine almış ve askeri yapının sivil siyasi iktidara alternatif olmasına imkân vermemişlerdir. Devrimlerle birlikte yeni ve demokratik bir başlangıç yapma imkânı bulan ordular da daha sonraki süreçlerde bütün bu değişimlere rağmen bu temiz demokratik başlangıç hedeflerinde sadık kalmayı başarmışlardır. ${ }^{66}$

Sivil-asker ilişkileri özelinde belki de en özgün ülke İsrail'dir. Ülkenin jeopolitik konumu, din referansı ve yayılmacı politikası, sürekli tehdit algısıyla beraber yaşıyor olması onu diğer devletlerden ayıran en karakteristik özellikleri arasındadır. Artan Filistin nüfusu ile Batı Şeria ve Gazze'de Filistin halkına karşı saldırıları, İsrail'in bu bölgeleri doğrudan tehdit görmesi sonucunda ortaya çıkan tehdit alg1sı, İsrail hükümetini istim üzerinde tutmaya yetmiştir. Güvenlik önceliğini ülke siyasetinin merkezine koyan İsrail, Mim Kemal Öke’ye göre "varlığını tanımayan ve onu Ortadoğu haritasından kazımaya uğraşan komşuları ile çevrili bu küçük devletin uluslararası ilişkilere bakış açısı hep güvenlik fobisinin oluşturduğu prizmadan" ${ }^{67}$ şekillenmektedir. Daha önce ABD bölümünde vurgulanan dış müdahale veya tehdit algısının, ordunun iç işlerine karışmasına engel olduğu düşüncesi, İsrail için geçerli değildir.

Nitekim Batı demokrasilerinin aksine İsrail farklı bir sivil-asker ilişkileri modeli sergilemektedir. Burada sivil siyasetçiler ile askeri kadrolar arasında ciddi bir ayrım bulunmamaktadır. Bu organik bağa rağmen, İsrail demokrasisi oldukça başarılı bir tecrübeye sahiptir. Bugün gelişmiş veya diğer tabirle konsolide olmuş Batı demokrasilerin aksine İsrail, demokratik olgunluğu, sivil-asker ilişkilerindeki uyuma borç-

64 Adrian Treacher, "A Case of Reinvention: France and Military Intervention in the 1990s", International Peacekeeping, 7/2 (2000), s.34-37.

65 Maryvonne L. Martin, "National Security and Democracy: The Dilemma from a French Perspective", Armed Forces and Society, 20/3 (1994), s.403.

66 Belge, Militarist Modernleşme, s.86-97.

67 Mim Kemal Öke, Din Ordu Gerilimi: Küresel Toplumda Dışlanan Demokrasi, İstanbul: Alfa Yayınları, 2002, s.336. 
ludur. Horowitz, Lissak ve Schiff ordu ve iktidar seçkinlerinin yakınlığını sadece demokrasiyi korumakla kalmadığı, aynı zamanda aralarında ortaya çıması muhtemel çatışmaları önlediği ve demokrasiyi tamamen ortadan kaldıracak darbe olasılıklarını azalttığını iddia etmektedirler. ${ }^{68} \mathrm{Bu}$ nedenle Huntington’un ideal sivil-asker ilişkileri şeklinde kavramlaştırdığı objektif sivil kontrol modeli, İsrail özelinde uygulanabilir görünmemektedir.

İsrail ordusu mensubu olan subay kadrosu, emeklilik döneminde de önemli görevlere getirilebilmektedir. $\mathrm{Bu}$ asker ile sivil siyasetin devamlı etkileşimde olduğunun da kanıtıdır. Ordu, siyasi hayatın ve politika yapım sürecinin ayrılmaz bir parçasıdır. Öyle ki ordunun siyaset hakkındaki görüşleri halkın gözü önünde tartışllabilmektedir. Genelkurmay Başkanı’nın kabine toplantılarına katılması da bu görüşü doğrulayan bir uygulamadır. ${ }^{69}$ İsrail'de sivil-asker ilişkileri konusunda çalı̧̧maları bulunan Peri de, büyük küçük her partinin aday listelerinde yüksek rütbeli subaylara yer vererek seçim kazanma şanslarını arttırdıklarını ileri sürmektedir. ${ }^{70}$ Demokrasinin evrensel prensipleri bağlamında olumlu adımlar gözlense de İsrail'de halen ordu-sivil ayrışması bulunmamaktadır. Öke, bu durumu şu şekilde tahlil etmektedir. Devletin ve milletin askerleşmesi yani İsrail militarizmi, ülkede pretoryan bir rejim riskini bertaraf etmiştir. Ordu, siyaset ve toplum ayrımının ortadan kalkması ülkede silahlı kuvvetlerin darbe gibi teşebbüslerde bulunmasını engellemektedir. ${ }^{71}$ Diğer taraftan Ortadoğu'daki mevcut siyasi istikrarsızlık sorunu, İsrail sivil-asker ilişkilerinin en azından bir müddet daha beraber gitmesini sağlamaktadır.

İspanya ise yukarıda kısaca değinilen Fransa ve İngiltere gibi ülkelerden farklı bir demokrasi tecrübesine sahip olmuştur. Sivil-asker ilişkileri bakımından Türkiye ile benzerlikleri bulunması, bizim için de İspanya’yı değerli kılmaktadır. İspanya rejimine bağlı olan ordu, yakın geçmişte "koruyucu" bir kimlikle hareket ederek kurucu felsefeye olan bağlllığını ortaya koymuştur. "İspanya birdir ve bölünmesine izin vermeyeceğiz" yaklaşımıyla hareket edip siyasete müdahale hakkını kendinde gören, kendisini "imtiyazlı" bir kesim olarak kabul eden ordu, İspanya’nın siyasi hayatında ciddi rol oynamıştır. ${ }^{72}$ Ordunun bu konumunda ise özellikle 19. yüzyıl siyasi çalkantılarının etkisi büyük olmuştur. 1936-1939 yılları arasında yaşanan İspanya İç Savaşı’nda Halk Cephesi'ne karşı milliyetçilerin komutanı olarak mücadele etmiş, faşist İtalya ve Almanyảnın desteğiyle zaferle çıkan ve parlamentoyu feshederek Katolik, milliyetçi muhafazakâr ve anti-komünist bir rejiminin başına geçen Franco, toplumu siyasi mücadelelerden uzak tutmak için demokratik kurumları kaldırmış, devlet güdümündeki resmi sendikalar hariç, diğer tüm sivil toplum örgütler ve siyasi partileri yasaklamış, yasama, yürütme ve yargı organlarını tek elde toplamıştır. ${ }^{73}$

68 Etzioni-Halevy, "Civil-Military Relations and Democracy", s.402-403.

69 Etzioni-Halevy, "Civil-Military Relations and Democracy", s.407.

70 Yoram Peri, Between Battles and Ballots: Israeli Military in Politics, Cambridge University Press, 1982, s.249.

71 Öke, Din Ordu Gerilimi: Küresel Toplumda Dışlanan Demokrasi, s.340.

72 Narcis Serra, Demokratikleşme Sürecinde Ordu, Silahl Kuvvetlerin Demokratik Reformu Üzerine Düşünceler, İstanbul: İletişim Yayınları, 2011, s.59-60.

73 Selin Esen Arnwine, “İspanyảda Diktatörlükten Demokrasiye Geçiş Süreci: 1975-1982”, Amme İdaresi Dergisi, 36/4 (2003), s.103-105. 
Ancak Franco’nun ölümü, İspanya için dönüm noktası oldu. Aslında Parlemento, Kraliyet Konseyi gibi belli başlı kurumlar Franco'nun yandaşlarının elinde olması nedeniyle var olan otoriter rejimin değişmeden devam edeceği umuluyordu. Fakat otoriter rejimin 1973'teki ekonomik bunalım, yeraltındaki partilerle sendikaların rejim karşıtı muhalefeti, yasadışı grevlerin yükselmesi, Franco'nun artan sağlık sorunları nedeniyle zayıfladığ 1 da iddia edilmekteydi. Toplumun tüm kesimleri ise demokratik bir dönüşümün iktidar eliyle değişebileceği konusunda beklenti içine girdi. Daha Franco hayattayken bile hareketlenmeler başlamış, ekonomik ve sendikal hak talepleri, öğrenci eylemleri hep bu değişimi isteyen çevrelerin eylemleri olarak görülmüştür. Özellikle Bask ve Katalan bölgesinde anadilde eğitim, özerk yönetim talepleri sistemi zor durumda bırakan gelişmeler olarak değerlendirilmiştir. ${ }^{74}$

Franco'dan yönetimi devralan Kral XIII. Alfonso'nun torunu Juan Carlos, demokratik parlamenter bir monarşinin sembolik yetkilerine sahip devlet başkanlığını tercih etmiştir. Akabinde pragmatik olarak gördüğü Adolfo Suarez'i başbakan olarak atamıştır. Suarez, hükümeti talep edilen reform sürecine toplumsal mutabakatı sağlayarak ve tüm toplum kesimlerinin desteğini alarak başlamış, ordunun desteğini en azından tarafsız kalmasını talep ederek hükümet reformlarına karşı koymasına engel olmuştur. Çünkü Franco'ya bağlılıkları bilinen ordu ikna edilemezse demokrasi sürecini nihaî hedefe ulaşması imkânsız kabul ediliyordu. Ordu konusundaki asıl demokratik baskı, Franco'nun seçtiği Kral Juan Carlos'tan gelmiş ve hedeflenen reformlar mecliste kabul edilmiştir. Sivil-asker ilişkilerindeki "uyum teorisinin” emarelerini taşıyan bu uzlaşı sayesinde, demokratikleşme yolunda ciddi siyasi reformlar hayata geçirilmiştir. Gerek seçimler gerekse seçimlerden sonra oluşacak olan Meclis ve Senato'nun daha ileri adımlar atabilmesi, halkoyuyla kabul edilen bu yasayla yapılabilmiştir. Siyasi parti yasakları kaldırılmış, Kilise’nin reformlara karşı çıkmasına engel olunmuş, yüksek enflasyon, artan diş ticaret açı̆̆ı ve işsizlik gibi ağırlaşan ekonomik sorunların çözümü de Parlamento'da 1977'de 'Mocloa Paktı' ile sağlanmıştır. ${ }^{75}$ $\mathrm{Bu}$ gelişmeler de sanayi burjuvazisinin Avrupa Birliği’ne girme talepleri de oldukça önemli bir etken olmuştur. 1978 yılında yapılan yeni anayasayla da milletlere ve bölgelere özerk yönetim hakkı tanınmış, ülkenin çok kültürlülügü ve çok dilliliği kabul edilmiştir. Atılan bu demokratik adımlar, ülkede demokrasinin pekişmesi amacıyla hayata geçirilmiş ve süreç öğrenciler, işçiler, girişimciler gibi sivil toplum kesimleri ile Kilise, siyasi partiler ve ordu mensupları gibi seçkinlerin etkili rol aldığı toplumsal bir mutabakatla sağlanmıştır.

Tabiî bütün bu süreç sıkıntısız geçmemiş, özellikle her şeyin yolunda gittiği bir anda gerek ülkenin üniter yapısının bozulmasından endişe edip söz konusu demokratik gelişmelerden rahatsız olan gerekse kendisine karşı yapılan bir takım yasal düzenlemelerden çekince duyan askeri kanat, ayrılıkçı terör örgütünün de kışkırtmasıyla 23 Şubat 1981 yılında darbe girişiminde bulunmuştur. Arnwine’a göre, İspanya Ordusu 1980 yılında Türkiye'de ordunun iktidarı ele geçirmesinden etkilenmiştir. ${ }^{76}$

74 Arnwine, "İspanya'da Diktatörlükten Demokrasiye Geçiş Süreci”, s.107-109.

75 Arnwine, "İspanyada Diktatörlükten Demokrasiye Geçiş Süreci”, s.113-116.

76 Arnwine, "İspanyada Diktatörlükten Demokrasiye Geçiş Süreci”, s.120. 
Bu girişimi destekleyenler arasında yer alan Franco yanlılarına sivil kesimden de çok sayıda destekçi vardı. Bunlar daha çok demokratikleşmeye karşı çıkan ve kendilerine "yeni güç" diyen faşist bir gruptu. Ordunun bu müdahalesini Serra üç faktörle açıklamaktadır. Ona göre;

- İspanya Ordusu mensupları, 1967 tarihli Devlet Teşkilatı Yasası gereği, kendilerini kurumsal düzenin garantörleri sayıyorlardı.

- Ordu, Franco’nun ölümünden sonra onun isteğiyle tahta çıkan Juan Carlos'a sadakatle bağlıdı.

- Ordu’yu, sivil toplumun paylaşmadığg ulusalcı değerlerin savunucusu ve koruyucusu olarak görüyorlard1. ${ }^{77}$

Müdahale sonrasında ordu kendi içinde ikiye ayrıldı; ancak gerek Kral Juan Carlos, gerek Başbakan Adolf Suarez gerekse muhalefet lideri Felipe Gonzales'in kararlı tutumları sayesinde ordu içindeki demokrasi yanlıları ağırlık kazandı ve darbe girişimi başarıya ulaşamadı. Serra’ya göre bunda İspanya ordusunun özerk bir kurum değil, devletin birçok organından sadece biri olduğunun anlaşılmasının ortaya çıkması önemli olmuştur. ${ }^{78}$ Her ne kadar Avrupa Birliğgine (AB) katılım süreci hayati derecede önemli olsa da İspanya'daki siyasi ve askeri aktörlerin demokrasi konusundaki kararlı tutumları hem İspanya’nın demokratikleşmesini sağlamış hem de AB sürecine katılmasını kolaylaştırmıştır.

Sonuçta İspanya’daki demokratikleşme süreci sivil-asker ilişkilerinin merkeze alınmasıyla etkili olmaya başlamıştır. Gerek yapılan yenilikler gerekse kabul edilen reform yasaları ve düzenlemeler, 1975 yılından 1990'lara kadar birçok kez gözden geçirilip değiştirilerek İspanya’nın demokratikleşmesini sağlamıştır. Bu sürecin ilk uygulamaları ordunun siyasete müdahalesini engelleyecek, özerk bir kurum gibi davranmasının önünü alacak ve Genelkurmay başkanının emir komuta zincirinin tepesinde yer almakla birlikte hükümet başkanına siyaseten bağlı olduğunu gösteren "sivil kontrolün" sağlandığı yapısal reformlarla yerine getirilmiştir.

Tıpkı İspanya gibi Türkiye’ye benzeyen bir diğer ülke de Yunanistan'dır. Coğrafi açıdan komşu olmaları, bu iki devleti, birçok konuda kesişen politikalar ve olaylar çerçevesinde ortak paydada buluşturmaktadır. Zaman zaman siyasi istikrarsızlıklar yaşayan bu iki ülkenin yakın tarihlerde askeri darbelere maruz kalması, oluşumu, gelişimi ve sonuçları bakımından bu darbelerin benzerlik göstermesi tesadüf değildir. Fakat Yunanistan'ın AB’ye üye olması ile birlikte, kendi iç düzeninde Avrupa’nın temel değerlerini kurumsallaştırmaya yönelik çabası, siyasi otoritenin sivilleşmesine olanak tanımış, siyasi dengeler demokratik bir yönetim temelinde kurulmuştur. Bağımsızlığın kabul edildiği 1828'den bugüne sayısız darbe ${ }^{79}$ tecrübesi yaşayan Yu-

77 Yasemin Çongar, “Ordu Nasıl Demokratikleriş-3, Askeri Vesayeti Bitirmenin Yolları” 2010, http://www. haberform.com/yazi/ordu-nasil-demokratiklesir-3-1647.htm (erişim 21.05.2013), s.4.

78 Çongar, "Ordu Nasıl Demokratikleriş-3", s.2.

79 “Darbe günlüğünü” 1831'de iki ayrı darbe ile başlatan Yunanistan, sırasıyla 1843, 1862, 1909, 1916, 1922, 1925 , 1926, 1935 ve en son 1967'de askeri darbelerle yüzleșmek durumunda kaldı. Bunlara ek olarak 1923, 1933, 1935, 1938, 1951, 1967 (ikinci kez), 1973 ve son olarak 1975’te başarısız ya da son anda önlenen darbe girişimleri 
nanistan, bugün demokratik gelişme yolunda ciddi mesafeler alarak yoluna devam etmektedir.

Yunan tarihine baktığımızda ordunun sık sık müdahalede bulunmuş olduğunu görmekteyiz. Bununda nedeni geçmişinde geleneksel mânâda bir "yönetici sınıfın” olmamasıdır. Bu yokluktan gelen siyasi boşluk, silahı elinde bulunduran ordu tarafından doldurulmuştur. ${ }^{80}$

1967-1974 yılları arasında askeri idareyle yönetilen Yunanistan, Avrupa’nın tam ortasında çok büyük bir demokrasi sorunu ile karşılaşmıştır. Albaylar Cuntası olarak bilinen bir dizi sağ görüşlü askeri yönetimin, 21 Nisan 1967 yılında ele geçirdikleri siyasi güç, 1974 yılında Türkiye’nin Kıbrıs’a müdahalesi sonucu gerilemiş ve yerini tekrar demokrasinin temel araçlarından biri olan sivil yönetime bırakmıştır. Askerî darbeye kadar uzanan sürecin temelinde, Yunanistan'daki monarşik düzenin hükümet sistemi ile çatışması yatmaktadır. ${ }^{81}$

Darbe, aşırı sol yapılanmaya karşı sert müdahaleler, sansürler, geniş çaplı tutuklamalar, anayasal hakların askıya alınması, bürokraside ve eğitim kurumlarında tasfiye sürecini beraberinde getirmiştir. 1968 yılında kabul edilen yeni anayasaya göre yürütmenin tüm yetkilerini elinde toplamış ordunun, devlet düzeninde öncelikli yere sahip olduğunu vurgulamıştır. Tüm bu süreçte, Avrupa Yunanistan'daki gelişmeleri kaygıyla karşılayarak baskı yapmaya çalışmıştır. ${ }^{82}$

Askeri cuntanın Kıbrıs’ta kurguladığı politikalar başarısızlıkla sonuçlanınca, gücü ve etkisi zayıflamaya başlamıştır. Kıbrıs Cumhurbaşkanı Makarios ile anlaşmazlığa düşen askeri yönetim, Enosis’e karşı darbe girişiminde bulunmuştur. Tam bu sırada, Türkiye'nin adaya çıkarma yaparak müdahalede bulunması, askeri yönetim için bunalımı derinleştirmiş ve sonunda yönetim sivillere bırakılmıştır. İktidarı eline geçeren Karamanlis başkanlığındaki sivil yönetim aşırı sağdan ilerici sola kadar birçok siyasal eğilimi temsil eden farklı görüşteki siyasi liderleri bir araya getirerek geçici hükümet kurmuş, sivil-kolluk güçleri arasındaki kopan bağı yeniden kurmak için, ordu, polis ve güvenlik güçlerinde tasfiyeler gerçekleştirmiştir. Darbeyi gerçekleştiren askeri cuntanın üst kadrosunu yargı önüne çıkartan Karamanlis, idam cezası almalarına karşın, darbe önderlerinin ömür boyu hapis ile cezalandırılmalarında etkili olmuştur. ${ }^{83}$

Darbe teşebbüsleri süreci 1981'deki temizlik operasyonu ve emir komuta zincirinin kırılmasıyla sona ermiştir. 1981 seçimlerinden \% 48 gibi ezici bir çoğunlukla çıkan PASOK lideri Andreas Papandreu, Yunan siyasi ve askeri tarihinde önemli adımlar

yaşand, bkz. Dimitris Tsarouhas, "Explaining an Activist Military: Greece until 1975”, Southeast European Politics, 6/1 (2005), s.1-13.

80 Belge, Militarist Modernleşme, s.777-778.

81 John S. Koliopoulus ve Thanos M. Veremis, Modern Grecee Since 1821, Wiley Blackwell, 2010, http://5595mg. s3.amazonaws.com/Modern-Greece-History.pdf (erişim 04.02.2015), s.142-143.

82 Bkz., Stelyo Berberakis, "Yunanistan darbe ve teşebbüsleri 31 yıl önce ortadan kaldırd»", Batı Trakya Haber Ajansı, erişim: 6 Nisan, 2019. https://www.batitrakya.org/yazar/stelyo-berberakis/yunanistan-darbe-vetesebbusleri-31-yil-once-ortadan-kaldirdi.html.

83Koliopoulus ve Veremis, Modern Grecee Since 1821, s.192-196. 
atmıştır. Kendisi iktidara gelir gelmez Yunan Silahlı Kuvvetleri içinde büyük bir temizlik operasyonu başlattı. Bu çerçevede ordunun tüzüğünde radikal değişiklikler yapmış ve Savunma Bakanlığı görevini de kendisi üstlenmiştir. Buna göre; "darbe hazırlıkları emrini alan; ya da aldığı emrin olası darbelere yol açabileceği kanısına varan alt rütbeli subaylara, hatta erlere, bir üstlerinden aldıkları bu emri cumhurbaşkanına, Başbakana ya da hükümet üyelerine bildirme yetkisi verildi”. Aynı tüzüğe göre, darbe ya da darbeye yol açabilecek emirleri alan ve bunu siyasetçilere bildirmeyen alt rütbeliler, bu emri aldıkları üstleri kadar "darbe yapmak ya da darbe teşebbüsünde bulunmak" suçu ile aynı derecede sorumlu gösterilecek ve ömür boyu hapis cezası hükmü giymeleri kaçınılmaz olacaktı. Yani bu değişikliklerle "yalnız ve yalnız darbe ya da darbe teşebbüsü şüphesi arz eden emir ve talimatlar için geçerli olması kaydıyla" Yunan Silahlı Kuvvetleri içindeki emir-komuta zinciri, demokratik bir biçimde ve demokrasi uğruna kırılmış oluyordu. 1831'den 1967 yılına kadar 12 askeri darbe ve 8 darbe teşebbüsüne şahit olan bugünün 10 milyonluk Yunanistan'ı, ancak 1981'de emir komuta zincirini kıran tüzük değişikliği ile Yunan halkı üzerinde adeta Demokles'in Kılıcı gibi sallanan "askeri vesayet korkusundan" arınabildi. ${ }^{84}$

Askeri cuntanın yönetimden çekilmesinden sonra Yunanistan, zaman zaman politik sisteminde tıkanıklıklar yaşasa da, genel anlamda sivilleşmiş parti sistemi ile demokrasinin işletilmesine özen göstermiştir. Elbette bunda, AB'nin payı inkâr edilemeyecek derecede önemlidir. AB üyeliği için yerine getirilen kriterler, Yunanistan'ın siyasi çerçevesini belirlerken, yapılan reformlar da AB’nin temel değerlerini göz önünde bulunduran yenilikleri içermektedir. Öyle ki, artık Yunan Genelkurmay Başkanı veya kuvvet komutanlarının adları bile geniş çapta bilinmez. Çağdaş Yunanistan için, genelkurmay başkanları ya da ordu komutanları «birer devlet memurudur.» Genelkurmay başkanı ise savunma bakanlarının "emrindedir". ${ }^{55}$ Özetle her ne kadar Yunanistan sayısız darbe teşebbüslerine maruz kalsa da geçmişinde barındırmış olduğu siyasi tecrübesi yani Sparta’yı değilde Atina'yı seçmesi, her şeyden önce "silaha" değil de "söze" önem vermesi ${ }^{86}$ ve orta sınıfın varlığında örgütlü toplum yapısı, söz konusu askeri müdahalelerin kalıcı olmasına fırsat vermemiştir.

Almanya ve Japonya’nın modernleşme süreçlerinin altında "askeri norm ve kuralları toplumun tamamına yani asker olmayan kesime de kabul ettirmeyi amaç edinmiş bir zihniyet" ${ }^{\prime 7}$ olan militarist modernleşme tecrübesi yatmaktadır. Toplumu modernleştirirken biçim vermeyi ve bir ulus devlet kurmayı amaçlayan militarizm, toplumun tamamını, çocukluktan başlayarak askeri değerler ve normlar çerçevesinde eğitmek, bu çerçevede davranmaya çağırmak, askerliği askerliğin dışına çıkarmak ve genel bir yaşama üslubu haline getirmek demektir. Bunun da anlamı bunu seçen toplumun yapmaya kalkıştığı her işi askeri yöntemle yapmaya karar vermiş olmasıdır. ${ }^{88}$

Gerek Almanya gerekse Japonya'da ordular, entelektüel dünyalarını kendi toplumla-

84 Bkz., Berberakis, "Yunanistan darbe ve teşebbüsleri 31 yıl önce ortadan kaldırdı”.

85 Tsarouhas, "Explaining an Activist Military: Greece until 1975”.

86 Belge, Militarist Modernleşme, s.782.

87 Belge, Militarist Modernleşme, s.147.

88 Belge, Militarist Modernleşme, s.150-164. 
rından tamamen koparmış ve yalnız kendilerine özgü belki "zümresel” denilebilecek bir ideoloji geliştirmişlerdir. Bu tavır onların devlet olarak tanıdıkları, aynı zamanda bir imparatorda da cisimleşen yüceliğe karşı bir ideolojik sadakat durumu haline gelmiştir. ${ }^{89}$ Bugün modernleşmiş ülkelerin hiç birisi, Almanya’nın sahip olduğu geniş bir sivil-asker ilişkileri kültürünü tecrübe etmemiştir.

Birliğini Almanya’yı kılıç ve kanla kuracağını söyleyen Bismarck’a borçlu olan bu ülke, kısa bir zaman içerisinde baş döndürücü bir başarıya ulus devlet bilinci ve ekonomik gelişmeyle ulaşmıştır. Avrupa'da güçlü bir ülke olmanın zorluğuna inanan Bismarck, sistemi ordunun kesin politik hâkimiyetine dayandırmıştır. Bismarck, iktidar denen şeyin kaynaklarını ve işleyişini çok iyi bildiği ve askerin potansiyel gücünü iyi hesapladığı için, anayasada askere doğrudan siyasi ayrıcalıklar tanıyan maddelere yer vermemişti. Ayrıca bütün siyasi deneyimiyle askeri olan veya olmayan bütün etkenleri, çevresindeki askerlerden daha iyi hesaplama özelliğine sahipti. O nedenledir ki asker de kendisine meydan okuma teşebbüsünde bulunmamıştır. Yani ordu kendisini, militarizmi kendi kadar iyi yapan Bismarck’ın yanında geri planda tutmuştur..$^{90}$ Ama güvence ortadan kalktığında da işlere el koymaya hazır olduğunu göstermiştir. Fransa, İngiltere ve ABD’de modernleşmede öncülük görevini yapan burjuva sınıfı Almanya'da da mevcuttu. Ancak burjuvazi burada modernleşmeyi hızlandıracak güce sahip değildi. O nedenle ordu bu süreçte etkin rol aldı. Öyle ki Almanya için “ordusu olan bir ülke değil, ülkesi olan bir ordu” tabiri kullanılmıştır. ${ }^{91}$

Modernleşmenin öncülüğünü aristokrasinin ve ordunun ele aldığı bir yönetim tarzında kimse bu militarist kültürün sonucunun Hitler ve Nazizm olacağını kestirememiştir. "Bismarck modeli birlik ve modernleşme, "zor" kavramını Alman toplumuna "tek geçerli gerçek" olarak tanıttığı ve benimsediği içindir ki Almanya (...) zor koşullarda Nazizimi seçti ya da Nazizm Almanya'ya kendini "en inandırıcı" yöntemin sahibi olarak gösterebilmişti". ${ }^{92}$ Bu manada militarizm, Nazizmin bir bekleme odası işlevini görmüştür.

Başa geçen Hitler bu militarist mirası alıp ülkeyi askerîleştirerek modernleşme çalışmalarına hız verdi. Askeri sivilleştirerek değil sivil toplumu askerileştirecek bir modeli uygulamaya soktu. Bürokrasiyi askerîleştirdi. Sanayi alanında atılan adımlarda askeri hedeflere öncelik verdi. Ekonomide de aynı yöntemi uygulandı. İşleyen ekonominin tek tek birimleri de toplumun merkezinde yer alan ordunun genel örgütlenme mantığıyla çalıştırıldı. Sanayiden tarıma kadar her bir fert üniformalı hale getirildi. İşverenler gibi işçilerde kendi çıkarlarından çok ulusal çıkarları gözetecek ölçüde organize edildi. Hedeflediği işleri salt askerle yapmayacağı anlayan Hitler, kendisine ait yarı askeri bir örgüt de kurdu ve bürokrasiyi, burjuvaziyi ve özellikle bürokrasinin askeri kanadını bu adamlarla idare etme yolunu tercih etti. Fakat sonrasında hırsları, Almanya’nın II. Dünya Savaşı'nı kaybetmesine ve I. Dünya Savaşı'ndan daha ağır bir hezimete uğramasına neden oldu.

89 Belge, Militarist Modernleşme, s.172.

90 Belge, Militarist Modernleşme, s.233-236.

91 Belge, Militarist Modernleşme, s.279.

92 Belge, Militarist Modernleşme, s.256. 
Bugün genel anlamda bakıldığında tarihten dersler çıkarmış bir Almanya vardır. Askeri yetkinin kapsamı, sadece askeri meselelerle sınırlı tutulmuş, yönetimi direkt savunma bakanlığına bağlanmış, sadece dış politikada görüşlerinin alınması olağan karşılanmıştır. Yapının bu şekli almasında Alman halkının korkularının ve savaş sonrası anayasanın da önemli bir payı vardır. Silahlanmaya karşı çıkan Alman halkı, siyasetin içine askerin karışmasını ve devletin içinde devlet olmasını kabul etmemiştir. ${ }^{93}$ Artık Alman toplumu, üçüncü seferde ve uluslararası destekle demokrasiyi kurmayı ve yaşatmayı, militarist geçmişiyle yüzleşerek başarmıştır. Bugün Avrupa’nın en güçlü ekonomisine sahip olan Almanya, kurucusu olduğu AB bünyesinde geçmişinden ders çıkarmış; ama geçmişini unutmayan bir anlayışla modern demokrasinin örneklerini sergilemektedir.

Demokrasisini değil; ama modernleşmesini II. Dünya Savaşınna kadar tamamlamış olan Japonya, karşımıza çıkan bir diğer militarist modernleşme örneğidir. ${ }^{94}$ Japonya’nın 1868'de başlayan Meiji Dönemi’ndeki modernleşme hamlesinde başlıca faktör, Türkiye'de olduğu gibi, Batı teknolojisinin üstünlüğünün anlaşılması ve uçurumun bir an önce kapatılması arzusudur. Yukarıdan aşağıya askeri bir seçkinler grubu eliyle yürütülen bu hareket, Batı'da var olan; ama geleneksel toplumlarda pek rastlanılmayan millet gibi soyut kavramlara dayandırılan ve millî çıkarları ön plânda tutan "milliyetçilikti".

1868'de modernleşme hareketini başlatan Meiji Dönemi liderlerinin önemli rolü kabul edilmekle beraber, Japonya’nın Batı’yı yakalamasında, merkezî hükümet bürokrasisi ile güçlü şirketlerin ve eğitim programlarının büyük rolü olduğu belirtilmektedir. Amaç, Japonya’nın kendi değerlerini koruyarak dünyanın efendisi olmasını sağlamaktı. Bunu da ancak toplumsal skalanın en üst basamağında yer alan askerin etkisiyle yerine getirdi. Meiji dönemi geçmiş dönemin askeri olan samurayları yok etmişti; ama modern ordu yönetici elitler arasında en üst basamağı işgal etti.

Eski Japonya'da her türlü ayrıcalık, savaşçı sınıfın elindeydi. Bu nedenle modernleşme hareketinin de bu sınıftan gelenler tarafından başlatılması kaçınılmazdı. Ama burada bir paradoks vardı, bir yandan modernleşme bu sınıf tarafından başlatılacak; ama bir yandan da kendisi yok olacaktı. Çözüm bireysel olarak samurayların yeni rejimin belirleyicileri ve yöneticileri kabul edilirken, diğer taraftan bir sinıf olarak samuraylığın ortadan kalkmasıydı. Nitekim bunda da başarı sağlandı, samuraylar modern ordunun bir unsuru haline geldiler; buna direnenlerse bastırılarak yok edildiler. $^{95}$

Batı tipi bir sanayileşme sürecine girmek için Japonya, önceki izolasyon dönemini terk ederek dünün "feodal ağaları", bugünün uluslararası dev şirketleri olan Zaibatsuların öncülüğünde modernizasyonu gerçekleştirdi. Bunda süratli değişim için gerekli direktifleri vermek üzere kurulan Japon bürokrasisinin de katkısı vardı. Bürok-

93 Öztürk, Ordu ve Politika, s.233.

94 Ömer Laçiner, “Türk Militarizmi-I-II”, Bir Zümre Bir Parti: Türkiye’de Ordu, Der. Ali Bayramoğlu, Ahmet İnsel, İstanbul: Birikim Yayınları, 2006, s.14.

95 Belge, Militarist Modernleşme, s.390-447. 
rasi Zaibatsularla beraber 20. yüzyılın ikinci yarısında, Japonya’nın endüstrileşmesini sağlayarak, bu ülkeyi "endüstri sonrası" bir toplum haline soktu. Meiji Dönemi’nde başarıyı ve modernleşmeyi sağlayan temellerden birisi de "merkezden yönetim" sisteminin Japonyada yürürlüğe sokulması olmuştur. Feodal dönemin idarî bölgeleri 1871'de kaldırılarak, yerine merkezden tayin edilen valilerle yönetilen vilâyetler esası kabul edilmiş ve silahlı kuvvetler de hükümetin denetimi altına sokulmuştur. ${ }^{96}$

Bugün Japonya II. Dünya Savaşı’ndan sonra ABD’nin de etkisiyle sivil, demokratik, liberal bir toplum yapısına kavuşmuştur. Bu bağlamda sağlanan en önemli gelişme ordunun gerçek anlamda etkisizleştirilmesidir. Savaşı kaybetmesinin sonucunda al1nan bu karar, 1946 Anayasası'nın 9. maddesinde yapılan düzenlemeyle sadece savunma amaçlı askeri güç bulundurmasiyla vücut bulmuştur. ${ }^{97}$

Günümüzde bulunduğu bölgedeki silahlanma yarışı, Japonya’yı güçlü bir orduya sahip olma ihtiyacını getirmiştir. Gelinen noktada Japonya’nın ulusal çıkarlarının ancak güçlü bir savunma gücü ile elde edilebileceği yaygın bir kanaattir. Bu bağlamda Japon ordusu, siyasetin bir unsuru olmaksızın salt Batı orduları gibi uluslararası sorunlarda sorumluluk alabilen bir yapıya kavuşmuştur.

\section{Sonuç}

Yukarıda da görüleceği üzere gelişmişliğini nihayete erdirmiş modern Batı ülkeler sivil-asker ilişkileri bağlamında farklı modeller ortaya koymuşlardır. Bu ülkelerin kendine has sivil-asker ilişkileri tecrübeleri ile toplumsal yapıları birbirinden farklı demokratik sistemlerin ortaya çıkmasına neden olmuşsa da son kertede gelişmiş evrensel demokratik ilkelerin kabul gördüğü bir sisteme evrilmesine bir engel teşkil etmemiştir. Bu ise söz konusu ülkelerin geçmişten günümüze intikal eden tecrübeleriyle oluşan sivil siyasi kültürün bir sonucudur. Nitekim demokratik açıdan farklı yönetim biçimlerine sahip olmasına rağmen gerek ABD, İngiltere gerekse Fransa sivil-asker ilişkileri bağlamında önemli mesafeler almış, Huntington’un askeri gücün en aza indirildiği ve sivil unsurların kendi güçlerini askerî unsurlar karşısında hâkim kılması şeklinde özetlediği sivil kontrol modelinin kabul gördügü bir demokrasi kültürünü geliştirebilmiştir. Kökleşmiş demokrasi tecrübesi ve sivil üstünlük ilkeleri bu anlayışta önemli bir rol oynamıştır. Ordu sadece dış politik alanda bir danışma organı olarak kabul edilmiştir. İsrail ise ideal demokrasi konusunda ciddi mesafeler almış olmasına rağmen sivil-asker ilişkileri göz önünde bulundurulduğunda Dougles Bland tarafından ortaya konmuş olan uyum teorisinin en çarpıcı örneği olarak karşımızda durmaktadır. Öyle ki üst kademedeki askeri yetkililer siyasi kararların alınmasına direkt katkıda bulunarak anahtar bir rol üstlenmişlerdir. Onun bu karakteristik özelliği jeopolitik konumu, din referansı ve yayılmacı politikası ile sürekli tehdit algısıyla beraber yaşıyor olmasından kaynaklanmaktadır. Diğer taraftan İspanya ve Yunanistan kendi geçmiş çalkantılı siyasi tecrübelerinden ders çıkararak demokratikleşme süreci içinde yol katedebilmişlerdir. Daha çok $\mathrm{AB}$ üyelik süreci içinde hayat bulan ve sivil-asker ilişkilerini önceleyerek sivil kontrolün sağlanması adına

96 Belge, Militarist Modernleşme, s.425-442.

97 Öztürk, Ordu ve Politika, s.247. 
kabul edilen reformlar ve yasal düzenlemeler bu ülkelerin demokratikleşme sürecine olumlu katkılar sağlamıştır. Geçmişinde militarist modernleşme tecrübesi yatan Almanya ve Japonya ise tarihten gerekli dersleri çıkarmış, sivil kontrolün sağlandığı Batı demokrasileri olarak karşımızda durmaktadır. Her iki ülkede de sistem demokratik, liberal bir toplum yapısına kavuşmuş, ordu siyasete müdâhil olma anlamında etkisizleştirilmiş, askeri yetkinin kapsamı sadece dış politika ve askeri meselelerle sınırlı tutulmuştur. Özetle, gelişmiş Batı demokrasilerinde birbirinden farklı sivil-asker ilişkileri tecrübeleri yaşanmış olsada ideal demokrasiye ulaşmak için üzerinde mutabık kalınan ortak demokratik değerlere ulaşma bağlamında bir çabanın sergilendiği görülmektedir. Söz konusu ideal hedefe ulaşmak için asıl önemli olan siyaset kurumunda ve toplumda içselleştirilmiş bir gayretin var olmuş olmasıdır.

\section{Kaynakça}

Albright, David. "Comparative Conceptualization of Civil-Military Relations". World Politics. 32/4 (1980): 553-576.

Almond, Gabriel ve Sidney Verba. Civic Culture. Erişim 4 Şubat 2015. http:// academic.regis.edu/jriley/205civiculture.

Atay, Agâh Sabri. Çok Partili Dönemde Türkiye'de Ordunun Siyasal Rolü ve Devlet Yapısı İçindeki Yeri. İstanbul: Anadolu Üniversitesi Yayınları, 1998.

Arnwine, Selin Esen. “İspanyada Diktatörlükten Demokrasiye Geçiş Süreci: 19751982”. Amme İdaresi Dergisi. 36/4 (2003): 103-126.

Belge, Murat. Militarist Modernleşme. İstanbul: İletişim Yayınları, 2011.

Berberakis, Stelyo. "Yunanistan darbe ve teșebbüsleri 31 yıl önce ortadan kaldırdı". Batı Trakya Haber Ajansı. Erişim 6 Nisan, 2019. https://www.batitrakya. org/yazar/stelyo-berberakis/yunanistan-darbe-ve-tesebbusleri-31-yil-onceortadan-kaldirdi.html.

Bland, Douglas. "Managing the 'Expert Problem' in Civil-Military Relations". European Security. 8/3 (1999): 25-43.

Burk, James. "Morris Janowitz and the Origins of Sociological Research". Armed Forces and Society. 19/2 (1993): 167-185.

Chittick, William O. "The Politicization of Security Policy". The Journal of Politics. 50/1 (1988): 180-191.

Crick, Bernard. Demokrasi. Çev., Ümit Hüsrev Yolsal. Ankara: Dost Yayınevi, 2012.

Çongar, Yasemin. "Ordu Nasıl Demokratikleriş-3, Askeri Vesayeti Bitirmenin Yolları”. Erişim 21 Mayıs 2013. http://www.haberform.com/yazi/ordu-nasildemokratiklesir-3-1647.htm, 2010.

Dahl, Robert. Demokrasi Üzerine. Çev., Betül Kadıoğlu. Ankara: Phoenix, 2010.

Dağcl, Gül Tuba. Osmanlidan Günümüze Ordu ve Siyaset İlişkisi. İstanbul: İlgi Yayınları, 2006.

Dandeker, Christopher. "The Military in Democratic Societies". Society. 38/6 (2001): $16-24$. 
Desch, Michael. "Soldiers, States, and Structures: The End of the Cold War and Weakening U.S. Civilian Control”. Armed Forces and Society. 24/3 (1998): 389405.

Diamond, Larry. “Is The Third Wave Over?". Journal of Democracy. 7/3 (1996): 20-37.

Duverger, Maurice. Siyasi Partiler. Çev., Ergun Özbudun. İstanbul: Bilgi Yayınevi, 1993.

Etzioni-Halevy, Eva. "Civil-Military Relations and Democracy: The Case of the Military-Political Elites' Connection in Israel”. Armed Forces and Society. 22/3 (1996): 401-417.

Finer, Samuel E. The Man on Horseback: The Role of Military in Politics. Middlesex: Penguin Books, 1975.

Huntington, Samuel. Üçüncü Dalga 20. yy. Sonlarında Demokratlaşma. Çev., Ergun Özbudun. Ankara: Türk Demokrasi Vakfı Yayınları, 2007.

Huntington, Samuel. "Civilian Control and the Constitution". The American Political Science Review, L (1956): 676-699.

Kelly, George A. “The Global Civil-Military Dilamma”. The Review of Politics. 25/3 (1963): 291-308.

Kışlalı, Ahmet Taner. Siyasal Sitemler, Siyasal Çatışma ve Uzlaşma. Ankara: İmge Kitabevi, 2003.

Kışlalı, Ahmet Taner. Kemalizm, Laiklik ve Demokrasi. Ankara, İmge Kitabevi, 1994.

Koliopoulus, John. S. ve Veremis, Thanos. M. Modern Grecee Since 1821, Wiley Blackwell, 2010. Erişim 4 Şubat 2015. http://5595mg.s3.amazonaws.com/ Modern-Greece-History.pdf.

Laçiner, Ömer. “Türk Militarizmi-I-II”. Der., Ali Bayramoğlu ve Ahmet İnsel. Bir Zümre Bir Parti: Türkiye’de Ordu. İstanbul: Birikim Yayınları, 2006.

Linz, Juan J. Totaliter ve Otoriter Rejimler. Çev., Ergun Özbudun. Ankara: Liberte Yayınları, 2008.

Lijphart, Arend. Çağdaş Demokrasiler. Çev., Ergun Özbudun ve Ersin Onulduran. Ankara: Yetkin Yayınları, 2002.

Martin, Maryvonne. L. "National Security and Democracy: The Dilemma from a French Perspective". Armed Forces and Society. 20/3 (1994): 395-421.

Meydan Gazetecilik. İstanbul, Meydan Larousse, cilt. 3,1987.

Moore, Barrington. Diktatörlüğün ve Demokrasinin Toplumsal Kökenleri. Çev., Şirin Tekeli ve Alaeddin Şenel. Ankara: İmge Kitabevi, 2012.

Öke, Mim Kemal. Din Ordu Gerilimi: Küresel Toplumda Dışlanan Demokrasi. İstanbul: Alfa Yayınları, 2002.

Örs, Birsen. Türkiye'de Askeri Müdahaleler Bir Açıklama Modeli. İstanbul: Der Yayıncilık, 1996.

Öztürk, Osman Metin. Ordu ve Politika. Ankara: Fark Yayınları, 2006.

Peri, Yoram. Between Battles and Ballots: Israeli Military in Politics. New York: Cambridge University Press, 1982. 
Perlmutter, Amos. "The Praetorian State and the Praetorian Army”. Comparative Politics. 1/3 (1969): 382-404.

Powell, Jonattan M. ve Clayton. L. Thyne. "Global Instances of Coups from 1950 to 2010: A New Dataset”. Journal of Peace Research. 48/2 (2011): 249-259.

Przeworski, Adam. Kapitalizm ve Sosyal Demokrasi. Çev., Naim Atabağsoy, Funda Çoban, İlkay Ata ve Soner Torlak. Ankara: Phoenix, 2012.

Sartori, Giovanni. Demokrasi Teorisine Geri Dönüş. Çev., T. Karamustafaoğlu ve M. Turhan. Ankara: Yetkin Yayınları, 1996.

Serra, Narcis. Demokratikleşme Sürecinde Ordu: Silahlı Kuvvetlerin Demokratik Reformu Üzerine Düşünceler. İstanbul: İletişim Yayınları, 2011.

Schiff, Rebecca. "Civil-Military Relations Reconsidered: A Theory Of Concordance". Armed Forces \& Society. 22/1 (1995): 7-24.

Tilly, Charles. Demokrasi. Çev., Ebru Arıcan. Ankara: Phoenix, 2007.

Touraine, Alain. Demokrasi Nedir?. Çev., Olcay Kunal. İstanbul: Yapı Kredi Yayınları, 2011.

Treacher, Adrian. "A Case of Reinvention: France and Military Intervention in the 1990s". International Peacekeeping. 7/2 (2000): 23-40.

Tsarouhas, Dimitris. "Explaining an Activist Military: Greece until 1975”. Southeast European Politics. VI/1 (2005): 1-13.

Turhan, Mehmet. Siyasal Elitler. Ankara: Gündoğan Yayınları, 2000.

Ünsaldı, Levent. Türkiye’de Asker ve Siyaset. İstanbul: Kitap Yayınc1lık, 2008.

Varol, Ozan O. “The Democratic Coup d'Êtat”. Harvard International Law Journal. 53/2 (2012): 292-356.

Yıldırım, “Mutlu. Türkiye’de Sivil Asker İlişkileri Bağlamında 1966-1973 Cumhurbaşkanlığı Seçimleri”. Yayınlanmamış Yüksek Lisans Tezi. Pamukkale Üniversitesi, 2010.

Yost, David. "France in the New Europe”. Foreign Affairs. 69/5 (1991): 107-128. 


\title{
Different Solutions for Civil-Military Relations in Advanced Western Democracies
}

\author{
MUTLU YILDIRIM
}

\begin{abstract}
Democracy is a form of government based on basic universal values such as political participation, freedom, human rights, equality, where the today's majority can turn into the future's minority, as well as the majority rights of minority rights. Although today it does not represent the different sections of the political faction, it is very difficult to find a regime that does not claim to be democratic. Despite the fact that such a large area has been influenced, however, the debate on democracy has not been adopted as a model of democracy that has not been finalized. The experiences of the different civil-military relations of the countries and the social structures led to the emergence of different democratic systems. But at the last point, especially in the case of developed Western countries evolving into a system of universal democratic principles accepted, the distance they have gained in civil-military relations and the political culture they have contributed. This study aims to show that developed Western countries have a common, reinforced democracy culture by shedding light on the experiences of different civil-military relations.
\end{abstract}

Keywords: Politics, Democracy, Western countries, Civil, Military. 